\title{
ŠTÁTNY ARCHEOLOGICKÝ ÚSTAV A JEHO AKTIVITY V ROKU 1940 VO SVETLE ARCHÍVNEHO VÝSKUMU
}

\author{
Martin Neumann* \\ * Katedra archeologie, Filozofická fakulta, Univerzita Komenskébo v Bratislave, Gondova 2, 811 02, Bratislava, \\ martin.neumann@uniba.sk
}

\begin{abstract}
State Archaeological Institute and its activities in 1940 in the light of archival research. In 1940 State Archaeological Institute celebrated its first anniversary. However, there was no reason for celebrating. Institute continually suffered under insufficient funding which negatively influenced its activities. During the first 5 months of 1940 no archaeological excavations took place. Only in June the first proper excavation began in Kožany. Nevertheless, even this excavation was affected by financial problems. However, the head of the Institute - Vojtech Budaváry - never gave up. He continued with his scientific research and rescuing of archaeological finds across the whole country at the same intensity. In this paper it will be tried to document his activities in 1940 which overlapped with activities of the Institute. New insight will be provided by research in the Archive of the former State Archaeological Institute.
\end{abstract}

Keywords: History of Archaeology, State Archaeological Institute, Vojtech Budaváry

Abstrakt: V roku 1940 oslavoval Štátny archeologický ústav prvý rok svojej existencie. Napriek tomu však nebol dôvod na oslavy. Ústav neustále trpel nedostatočným financovaním, ktoré negatívne ovplyvňovalo jeho aktivity. Počas prvých piatich mesiacov roku 1940 neboli uskutočnené žiadne terénne akcie. Až v júni začal prvý riadny archeologický výskum v Kožanoch. Aj tento sa však musel borit’ s finančnými problémami. Napriek tomu riaditel' ústavu - Vojtech Budaváry nikdy nepolavil vo svojich aktivitách. Pokračoval vo výskumoch a v záchrane archeologických pamiatok po celej krajine. V tejto práci budú zdokumentované jeho aktivity v roku 1940, ktoré sa prekrývali s činnost’ou ústavu. Nový pohlad na jeho činnost’ prinesú predovšetkým dostupné dokumenty z archívu bývalého Štátneho archeologického ústavu.

K’’účové slová: história archeológie, Štátny archeologický ústav, Vojtech Budaváry

https://doi.org/10.46283/musarch.2020.1.06

\section{1. Úvod}

V roku 1940 oslavoval Štátny archeologický ústav prvé výročie svojej existencie. ${ }^{1}$ Takmer 10 mesiacov, ktoré uplynuli od jeho založenia, mohlo poskytnút' dostatok času na vyriešenie neodkladných existenčných otázok novo založenej inštitúcie a na prispôsobenie každodenného programu riaditel’a a zároveň jediného zamestnanca ústavu Vojtecha Budaváryho. ${ }^{2}$ Ten okrem plnenia povinností riaditela Štátneho archeologického ústavu súčasne prednášal aj na univerzite v Bratislave. ${ }^{3}$ Osud Štátneho archeologického ústavu však neležal výhradne v rukách jeho riaditela.

1 K okolnostiam vzniku samostatného Štátneho archeologického ústavu na Slovensku pozri Neumann 2019. Na tomto mieste len uved'me, že od svojho vzniku v roku 1939 sídlil ústav v tradičnom kultúrnom centre Slovákov - Turčianskom Sv. Martine (sídlilo tu i Slovenské národné múzeum, s ktorým bol Štátny archeologicky ústav organizačne previazaný). Jeho prvým riaditelom bol Vojtech Budaváry.

2 Vojtech Budaváry (1903 - 1993) - na Univerzite Komenského v Bratislave vyštudoval dejepis, zemepis a národopis, v rokoch 1929 - 1933 bol kustódom historického oddelenia v Slovenskom národnom múzeu v Turčianskom Sv. Martine, následne odišiel do Prahy, kde bol do roku 1939 zamestnancom Štátneho archeologického ústavu. Po návrate na Slovensko sa v roku 1939 stal prvým riaditelom slovenského Štátneho archeologického ústavu. V tejto funkcii zotrval až do roku 1951 (Sklenár 2005, 98).

3 V roku 1940 bola Univerzita Komenského na základe zákona č. 168/1940 Sl. z. premenovaná na Slovenskú univerzitu. Tento názov niesla až do roku 
Existenčne bol závislý od pravidelných štátnych dotácií pridel’ovaných Ministerstvom školstva a národnej osvety (d’alej MŠANO). Ich výška priamo ovplyvňovala a určovala každodenný program ústavu. Od súhry uvedených faktorov preto bezvýhradne záviselo potvrdenie ,životaschopnosti“ tejto inštitúcie. Za účelom overenia spomínanej „životaschopnosti" sme pristúpili k podrobnému zmapovaniu aktivít Štátneho archeologického ústavu v priebehu roka 1940. ${ }^{4}$ Ich výsledky sú dnes z vel'kej časti na rôznych miestach publikované formou krátkych správ či obšírnejších štúdií (zhrňujúco s d’alšou literatúrou Budinský-Krička 1993). Separátne publikované správy o výsledkoch aktivít ústavu síce podávajú podrobné informácie o okolnostiach nálezov, výsledkoch archeologických prieskumov či výskumov, no v dôsledku ich rozptýlenosti ich nedokážu zasadit’ do kontextu celkovej aktivity ústavu. Zásadný pohl’ad v tomto smere ponúkajú dobové novinové správy a predovšetkým archívne dokumenty z fondu Štátneho archeologického ústavu. V predkladanej práci sa preto na ich základe pokúsime vytvorit’ časový harmonogram rôznorodých činností Štátneho archeologického ústavu (reprezentovaného v roku 1940 len osobou V. Budaváryho). Aktivity ústavu budeme predstavovat' v takom poradí, v akom boli v roku 1940 realizované. Ciel'om bude nielen pokus o zdokumentovanie spektra aktivít riaditela Štátneho archeologického ústavu - V. Budaváryho, no i rekonštrukcia pozadia výskumných aktivít tejto mladej inštitúcie. Dúfame, že ponúknutý náhl’ad poskytne nielen odpoved’ na potvrdenie či vyvrátenie tézy o „životaschopnosti“ Štátneho archeologického ústavu, no bude i prínosnou a pútavou sondou do jeho života.

\section{Jar - čakanie na leto}

Počiatočné mesiace roku 1940 sa V. Budaváry pravdepodobne venoval práci s nálezmi a dokumentáciou uloženou v ústave. Vybavoval aj nevyhnutnú korešpondenciu, ktorá priamo alebo sprostredkovane oznamovala ústavu nové archeologické nálezy z celého Slovenska. Absenciu terénnych akcií v tomto období by mohol vysvetl'ovat' nedostatok finančných prostriedkov, s ktorými mohol ústav počas jarných mesiacov disponovat'. Prvá štvrt'ročná dotácia vo výške 3000 Ks bola ústavu pridelená až 15. marca. ${ }^{5}$ Riaditel' ústavu sa pravdepodobne pre nedostatočné finančné zabezpečenie činnosti ústavu obmedzil len na zasielanie pokynov či žiadostí o podrobnejšie informácie prostredníctvom pošty. Takto napríklad žiadal Štátnu meštiansku školu v Krupine o zaslanie náčrtov „urien“ z Opatovských Moraviec (okr. Krupina) či správcu školy v Mikušovciach o poskytnutie nálezov nájdených v Mikušovciach (okr. Ilava) v polohe „Kopce“ ${ }^{6}{ }^{6} \mathrm{~V}$ prípade Mikušoviec dokonca žiadal správcu školy - Ladislava Matejíčku - o určenie rozmerov prípadných mohýl nachádzajúcich sa v tejto polohe. $\mathrm{O}$ d’alšom výnimočnom náleze sa riaditel' ústavu dozvedel prostredníctvom Jána Krajčíka, študenta filozofie na univerzite v Bratislave. ${ }^{8} \mathrm{~V}$ kláštore školských bratov v Bojnej (okr. Topol’čany) mali byt' uložené viaceré predmety, ktoré boli objavené pri kopaní cesty pod „Valiskom“.? V. Budaváry preto koncom apríla adresoval kláštoru list, v ktorom žiadal o krátku správu o spomínaných nálezoch. ${ }^{10}$

1954, kedy sa vrátila spät’ k svojmu pôvodnému názvu (Vojáček - Kolárik - Gábriš 2011, 38).

4 K aktivitám Štátneho archeologického ústavu v roku 1939 pozri Neumann 2019.

5 Len pre porovnanie uved’me, že mesačný plat V. Budaváryho v tomto období činil 1228,20 Ks. Ďalšia štátna dotácia (v rovnakej výške ako v marci) bola ústavu pridelená až 8 . júna. V období medzi 15. marcom a 8. júnom nemal ústav žiadne iné príjmy.

Archív SAV, f. AÚ SAV - Rozpočet a systematizácia, zn. B X, inv. č. 461, č. j. 55/1941, škat. č. 81.

6 Archív SAV, f. AÚ SAV - Spolupráca s inštitúciami, zn. B VII, inv. č. 269, č. j. 6/1940, škat. č. 55.

Riaditel’stvo školy v Krupine skutočne poslalo náčrt urny, no zároveň V. Budaváryho upozornilo, že Slovenské národné múzeum už dávnejšie udelilo istému českému nadporuč́kovi Vyskočilovi poverenie „sbierat’ veci z vykopávok“. Ten si však mnohé z nich ponechal a d’alšie odpredával na Moravu. Ďalšie urny mal mat' podl'a informácií riaditel'a školy aj vládny komisár Pavol Párničan (P. Párničan bol od roku 1933 členom HSL’S, do roku 1938 bol okresným tajomníkom strany, následne sa stal námestníkom starostu a vládnym komisárom, od roku 1944 do februára 1945 bol mešt’anostom Krupiny; Hruboň 2010, 97-98).

Archív SAV, f. AÚ SAV - Spolupráca s inštitúciami, zn. B VII, inv. č. 269, č. j. 9/1940, škat. č. 55.

7 Archív SAV, f. AÚ SAV - Spolupráca s inštitúciami, zn. B VII, inv. č. 269, č. j. 7/1940, škat. č. 55.

V. Budaváry navštívil Mikušovce osobne 29. augusta (pozri d’alej v texte).

8 Ján Krajčík z Bojnej sa nachádza v databáze osôb, ktorým bol Univerzitou Komenského vydaný diplom. V období 40 . rokov tu figuruje len jedna osoba s rovnakým menom (a tiež pôvodom z Bojnej), ktorá však študovala fyzikálny zemepis a zemepis Slovenska na Prírodovedeckej fakulte. Titul RNDr. mal J. Krajčík získat' v roku 1946. Nie je isté, či je daná osoba totožná s „poslucháčom filozofie“ J. Krajčíkom.

Pozri tu: https://absolventi.uniba.sk/index.do

9 Malo íst' o „sekeru, krčiažtek, meč“ a d’alšie železné predmety.

Archív SAV, f. AÚ SAV - Spolupráca s inštitúciami, zn. B VII, inv. č. 269, č. j. 46/1940, škat. č. 55.

10 Odpoved' kláštora nie je $\mathrm{v}$ archíve (Archív SAV, f. AÚ SAV) evidovaná. 
Z predchádzajúcich príkladov bolo zrejmé, že riaditel' ústavu len inštruoval adresátov svojich listov o d'alšom postupe. V prípade nálezu z Podrečian (okr. Lučenec) však urobil výnimku. Muzeálna slovenská spoločnost’ ho informovala o liste okresného náčelníka z Lovinobane, ktorý jej oznamoval objav viacerých keramických nádob v podrečianskom kameňolome. ${ }^{11}$ V. Budaváry sa 15 . mája vydal na cestu do Podrečian. ${ }^{12}$ Nález keramiky na tunajšom žiarovom pohrebisku podnietil riaditel’a ústavu k definovaniu tzv. podrečianskeho typu, ktorý bol odlišný od keramiky lužickej, no i pilinskej kultúry (Furmánek 1986, 322). ${ }^{13}$ Počas svojej pracovnej cesty pravdepodobne navštívil aj okresný úrad v Lovinobani (okr. Lučenec), kde boli uložené 4 nádoby z pohrebiska narušeného kameňolomom (Budinský-Krička 1945-46, 264).

Riaditel' ústavu pozorne sledoval aj každodennú tlač, kam sa občas dostali aj správy o náhodných archeologických nálezoch (obr. 1). Okamžite sa snažil na takéto správy reagovat’ a zaistit' riadnu starostlivost' o ne. Týkalo sa to aj nálezu „hrobu“ na Tisovom námestí v Nitre (okr. Nitra), ktorá sa objavila v Slovákovi 5. júna. ${ }^{14}$ Počas úpravy námestia sa tu na „hlbšom mieste“ pred mestským divadlom našiel pozoruhodný nálezový celok pozostávajúci

- Zaujimavé vykopávky v Nitre. Ako známo, upravuje sa i Nitre Tisovo námestie pred Mestským divadlom. Pri kopaní našly sa na hlbšom mieste konské podkovy, jedna dýka, dve strieborné ostrohy, predná čiastka lebky býka i s krátkymi mocnými rohami a hrubou refazou, a spojené dve okovy. Zaujimavé je, ̌̌e pri týchto veciach ležala aj kostra ěloveka úplne spráchnivelá. Je všejbecná domnienka, že na tomto mieste je prastarý cintorín, alebo pohrebisko z tureckých ěasov. Mestı bude pravdepodobne kopaf hlbšie $\mathrm{k}$ vôli zisteniu, či sa tu skutočne nachádza niečo z dávnyeh ěias, - L.

Obr. 1. Novinová správa o archeologických nálezoch na Tisovom námestí v Nitre (Slovák, 5. jún 1940, č. 130, s. 6).

Fig. 1. Newspaper article about archaeological finds at Tiso Square in Nitra (Slovák, 5. jún 1940, č. 130, s. 6). z konských podkov, jednej dýky, dvoch strieborných ostrôh, hrubej ret'aze, dvoch spojených okov a prednej časti býčej lebky spolu s rohami. ${ }^{15} \mathrm{~V}$. Budaváry preto požiadal správu Krajinského múzea v Nitre, aby ho informovala o uložení nálezov a zároveň mu poslala náčrty alebo fotografie hrobu nájdeného pred budovou mestského divadla. ${ }^{16}$

Okrem evidovania archeologických nálezov v Slovenskom národnom múzeu, inventarizácie nálezov a príležitostných výjazdov na obhliadky do terénu sa V. Budaváry počas jarného obdobia venoval aj prednáškovej činnosti. Ako kustód historického oddelenia v Slovenskom národnom múzeu sa 28. apríla zúčastnil valného zhromaždenia Muzeálnej slovenskej spoločnosti. $\mathrm{Na}$ ňom zástupcovia jednotlivých muzeálnych odborov referovali o svojej činnosti. Svoju činnost' tu prezentoval aj V. Budaváry. ${ }^{17}$ Okrem toho ponúkol svoje prednášky aj širšiemu publiku. Počas roka vystupoval v Bratislave, Bardejove, Prešove, Ružomberku a Liptovskom Mikuláši. ${ }^{18}$

\footnotetext{
11 Archív SAV, f. AÚ SAV - Spolupráca s inštitúciami, zn. B VII, inv. č. 269, č. j. 54/1940, škat. č. 55.

12 Archív SAV, f. AÚ SAV - Rozpočet a systematizácia, zn. B X, inv. č. 461, č. j. 55/1941, škat. č. 81.

13 Názov sa však neujal a o pár rokov neskôr bol nahradený termínom kyjatický typ (Filip 1948, 204; Furmánek - Veliačik 1980, 170).

14 Zaujímavé nálezy v Nitre. Slovák, 5. jún 1940, roč. 22, č. 130, s. 6.

V roku 1940 sa v Nitre realizovalo viacero rekonštrukcií verejných priestranstiev. Jedným z nich bolo aj Tisovo námestie (dnešné Svätoplukovo námestie), kam mala byt' zavedená kanalizácia s vodotriskom a celý priestor námestia mal byt’ skrášlený zeleňou..

V Nitre upravujú Tisovo námestie. Slovák, 29. máj 1940, roč. 22, č. 124, s. 6.

15 Zaujímavé nálezy v Nitre. Slovák, 5. jún 1940, roč. 22, č. 130, s. 6.

Viaceré hroby z rôznych období (strašia doba bronzová, včasný stredovek) boli na Svätoplukovom námestí a jeho bezprostrednom okolí objavené a preskúmané aj v neskorších rokoch (Ruttkeay 2007, 131, 139; Ruttkeay 2018).

16 Archív SAV, f. AÚ SAV - Spolupráca s inštitúciami, zn. B VII, inv. č. 269, č. j. 91/1940, škat. č. 55.

17 V 1939 sa podarilo Slovenskému národnému múzeu získat’ zbierku Jána Sabova z Ivanky pri Nitre, ktorá obsahovala nálezy od neolitu až po dobu hradištnú. Rovnako získalo múzeum aj zbierku nálezov prof. Karola Silnického z jaskyne „Na vyhni“ pri Turčianskej Blatnici, bronzové predmety z Lehôtky, nálezy zo staršej doby bronzovej z Nitry a keramiku z Hrádku pri Priekope. V. Budaváry osobne prezrel náleziská hrobov v Kapušanoch a preskúmal niekol'ko hrobov v Nemečkách pri Topol'čanoch (Neumann 2019, 16). Okrem toho sa intenzívne venoval inventarizácii a konzervovaniu uskladnených zbierok.

Lanská práca Slovenského národného múzea (Z činnosti jednotlivých odborov). Slovák, 8. máj 1940, roč. 22, č. 107 , s. 7.

18 Témou prednášok bol výskum pravekých a staroslovanských mohýl na Slovensku. Je pravdepodobné, že téma prednášky sa týkala výskumov V. Budaváryho na východnom Slovensku. Ked'že tieto sa realizovali v júni, júli, novembri a decembri (pozri d'alej v texte), museli sa aj tieto prednášky odohrat' niekedy medzi júnom a decembrom tohto roka. Okrem toho predniesol na kurze Zväzu slovenských múzeí prednášku na tému Archeologický výskum Slovenska a naše múzeá (Prehl’ad prác 1941, 54).
} 


\section{Leto - vlastné terénne aktivity}

S príchodom letných mesiacov (a tým pádom aj uvol’nením z výučby na univerzite) plánoval V. Budaváry presunút' svoje aktivity na východné Slovensko. Jeho pozornost' upútali mohylové násypy v okolí Kožian a Kurimy (okr. Bardejov), o ktorých ho informovalo obecné notárstvo v Bardejove. ${ }^{19}$ Tomu predal správu objavitel' mohýl - Bartolomej Krpelec, školský inšpektor vo výslužbe (Budinský-Krička 1967, 284). ${ }^{20}$ „Pohanské hroby“, ako ich sám nazval, objavil v lete roku 1939. V. Budaváry z ich opisu pravdepodobne vedel, čo môže očakávat', a preto požiadal B. Krpelca o bližší popis týchto „hrobov" s tým, že by tam mohol podniknút' sústavný výskum. ${ }^{21}$ Pri návšteve katastra Kožian a Kurimy začiatkom mája V. Budaváry mohylové násypy skutočne našiel a predbežne ich datoval do „staroslovenského“ obdobia. Hned’ tu aj začal plánovat’ výskum..$^{22}$ Ministerstvu školstva a národnej osvety zaslal v polovici mája predbežný rozpočet. Na mzdy robotníkov, ktoré malo v najlepšom prípade zabezpečit' Ministerstvo národnej obrany, malo byt' vyčlenených $4500 \mathrm{Ks} .{ }^{23}$ Cestovné náklady si mali vyžiadat' $1400 \mathrm{Ks}$ a ako odškodné za prípadný výrub stromov malo byt' rezervovaných 500 Ks. Pôvodne zamýšlal príst' do Kožian už 8 . júna, no napokon sem dorazil až o desat' dní neskôr. ${ }^{24}$ Plánoval tu zotrvat' pät’ týždňov. To ešte netušil, že sa tu v dôsledku finančných t’ažkostí posledný tohoročný výkop ukončí až 9 . decembra. ${ }^{25} \mathrm{Aj}$ to však nemala byt' definitívna bodka - výskumy v okolí Giraltoviec vyplńali program Štátneho archeologického ústavu ešte niekol'ko rokov.

Začiatok výskumu v Kožanoch sa kvôli ceste do Krivoklátu (okr. Ilava) musel o niekol'ko dní odložit'. Dňa 29. apríla 1940 tu totiž žiak P’udovej školy Ondrej Bezdeda objavil počas pasenia oviec bronzovú sponu (Černušková 2018, 24). Skrývala sa pod mohutnou vápencovou skalou (balvanom) v údolí krivoklátskeho potoka. ${ }^{26}$ O náleze sa dozvedel správca miestneho oddelenia finančnej správy Máchal, ktorý nález zaistil, vyhotovil náčrt, spísal úradnú zápisnicu ${ }^{27}$ a už 4. mája upovedomil Okresný úrad v Púchove nad Váhom. ${ }^{28} \mathrm{O}$ mesiac neskôr už MŠANO informovalo Štátny archeologický ústav a žiadalo o zaujatie stanoviska $\mathrm{k}$ danej veci. ${ }^{29} \mathrm{~V}$. Budaváry na základe opisu a náčrtu spony okamžite rozpoznal, že ide o výnimočný nález, ktorý v zbierkach slovenských múzeí chýba. Jediná podobná spona „zo staršej periody hallštattskej kultúry“ bola nájdená v Krásnej Hôrke - Medvedzí, no tá bola uložená v Národnom múzeu v Budapešti. Na základe skúseností s podobnými nálezmi vedel, že spona mohla byt’ „čiastkou pokladu“ (depotu). Rozhodol sa preto, že v čo najkratšom čase osobne navštívi Krivoklát ako i blízke Mikušovce, odkial' získal ústav fragment „,vázy“ a 2 bronzové „šperky“. ${ }^{30}$ Svoj príchod oznámil Oddeleniu finančnej stráže na 12. júna. ${ }^{31}$ Po svojom príchode zistil, že spona bola čiastočne poškodená det'mi, ktoré sa s ňou nejaký čas hrali. Napriek tomu odmenil nálezcu - O. Bezdedu - nálezným vo výške 100 Ks. Zároveň mu nálezca ukázal samotné miesto nálezu, ktoré V. Budaváry prebádal spolu s troma robotníkmi - Štefanom Bezdedom, Cyrilom Bezdedom a Cypriánom Pagáčom. ${ }^{32}$ Ked’že sa na mieste nenašli „ani pozostatky kostí, ktoré by svedčili o hrobe, ani vrstva kultúrna, ktorá by ukazovala na sídlište, ani d’alšie bronzové predmety, ktoré by svedčili o hromadnom náleze“, označil sponu za „nález ojedine-

19 Archív SAV, f. AÚ SAV - Spolupráca s inštitúciami, zn. B VII, inv. č. 269, č. j. 8/1940, škat. č. 55.

20 Bartolomej Krpelec sa v roku 1943 stal tajomníkom Štátneho archeologického ústavu pre okres Bardejov (Neumann 2020).

21 Archív SAV, f. AÚ SAV - Spolupráca s inštitúciami, zn. B VII, inv. č. 269, č. j. 8/1940, škat. č. 55.

22 Archív SAV, f. AÚ SAV - Vedecká činnost', zn. B V, inv. č. 200, č. j. 66/1940, škat. č. 21.

23 Ministerstvo národnej obrany robotníkov nakoniec nezabezpečilo. V. Budavárymu na výskume vypomáhali obyvatelia z okolitých obcí.

24 Archív SAV, f. AÚ SAV - Vedecká činnost', zn. B V, inv. č. 200, č. j. 66/1940, škat. č. 21.

Archív SAV, f. AÚ SAV - Vedecká činnost', zn. B V, inv. č. 200, č. j. 124/1940, škat. č. 21.

25 Archív SAV, f. AÚ SAV - Vedecká činnost', zn. B V, inv. č. 200, č. j. 359/1940, škat. č. 21.

26 Archív SAV, f. AÚ SAV - Vedecká činnost', zn. B V, inv. č. 200, č. j. 110/1940, škat. č. 21.

27 Zápisnica bola spisovaná s Cyrilom Bezdedom - je možné, že bol príbuzným (otcom?) spomínaného Ondreja Bezdedu.

28 V liste okresnému úradu bolo uvedené, že spona bola čiastočne poškodená a „hodne okysličená“. Na základe toho sa súdilo, že sa na miesto nálezu dostala ešte v časoch, kedy bol ešte obývaný hrad Vršatské Podhradie. Bola pridaná aj poznámka k jej funkcii - mala údajne slúžit’ na ,zapätie haleny cez prsia".

Archív SAV, f. AÚ SAV - Vedecká činnost', zn. B V, inv. č. 200, č. j. 95/1940, škat. č. 21.

29 Archív SAV, f. AÚ SAV - Vedecká činnost', zn. B V, inv. č. 200, č. j. 95/1940, škat. č. 21.

30 Do Mikušoviec zavítal V. Budaváry už v auguste (pozri d’alej v texte).

31 V liste je ako dátum plánovaného príchodu do Krivoklátu uvedený 12. máj, no samotný list je datovaný 10. júnom. Toho istého dňa (10. júna) dostal Štátny archeologický ústav vôbec prvé upovedomenie o náleze od Ministerstva školstva a národnej osvety. Očividne musí íst' v prípade májového dátumu o mesačný posun v datovaní plánovaného príchodu do Krivoklátu.

Archív SAV, f. AÚ SAV - Vedecká činnost', zn. B V, inv. č. 200, č. j. 95/1940, škat. č. 21.

32 Archív SAV, f. AÚ SAV - Rozpočet a systematizácia, zn. B X, inv. č. 461, č. j. 55/1941, škat. č. 81. 
lý‘ “.33 Ked’že vo fondoch slovenských múzeí sa podobný nález ešte nenachádzal, požiadal MŠANO o jeho vystavenie v Slovenskom národnom múzeu. ${ }^{34}$ To sa nakoniec aj podarilo.

Po overení nálezových okolností v Krivokláte sa V. Budaváry mohol konečne vydat' na východné Slovensko. Pred odchodom z Turčianskeho Sv. Martina si však zadovážil nový zápisník, remene a plátennú tašku, pravdepodobne pre potreby výskumu. ${ }^{35}$ Práce v teréne teda začal riaditel’ ústavu s istým oneskorením až 18 . júna a sústredil sa najmä na oblast' tzv. Blatného vrchu na pomedzí katastrov obcí Kožany a Kurima. ${ }^{36}$ Pri terénnych prácach pomáhali predovšetkým miestni obyvatelia z Kožian. Väčšinou bola nasadená skupina ôsmych až dvanástich robotníkov, ktorí pracovali desat' hodín denne. ${ }^{37}$ Priemerný zárobok za hodinu boli $2,50 \mathrm{Ks}^{38}$

Počas letnej expedície na východnom Slovensku sa V. Budavárymu podarilo v priebehu roka preskúmat' niekol’ko mohýl. ${ }^{39}$ Väčšina z nich skrývala nespálené telá l’udských jedincov, ktoré však boli z vellkej časti strávené pôdou..$^{40}$ Prvá preskúmaná mohyla, ktorá dosahovala priemer $10 \mathrm{~m}$, mala na výšku len $80 \mathrm{~cm}$. V jej zásype sa našli zlomky keramických nádob, uhlíky a starostlivo opracovaný kamenný nástroj, ktorý ležal v strede mohyly na úrovni pôvodného terénu. Druhá mohyla s výškou $1,1 \mathrm{~m}$ a priemerom $9,5 \mathrm{~m}$ ukrývala zvyšky rozsiahleho ohniska. ${ }^{41}$ Tretia mohyla s rozmermi $1,3 \mathrm{~m}$ na výšku a $12 \mathrm{~m}$ v priemere sa svojím obsahom neodlišovala od predchádzajúcich dvoch. ${ }^{42}$ Z odokrytých nálezov stojí za zmienku len kamenné „struhadlo“ priamo zo zásypu mohyly. Aj tu sa priamo na pôvodnom povrchu našli zvyšky ohniska. Štvrtá mohyla bola oproti ostatným o niečo menšia. Na priemer merala len $9 \mathrm{~m}$, na výšku $40 \mathrm{~cm} .{ }^{43}$ Ani svojím obsahom sa neodlišovala od ostatných (keramické fragmenty, kamenný nástroj a úštep). Ovela zaujímavejšia bola piata mohyla s priemerom $10,5 \mathrm{~m}$ a výškou $1 \mathrm{~m} \cdot{ }^{44}$ Pod jej násypom sa nachádzali žiaroviská s čast’ami ludských kostí, 3 hlinené prasleny a kamenná čepel'. ${ }^{45}$ Poslednou mohylou, ktorú V. Budaváry v júli preskúmal, bola mohyla VI. Na jej odkrývaní sa podielalo dvanást’ robotníkov, medzi nimi i poslucháč filozofie a správca školy Viktor Šemmer. ${ }^{46} \mathrm{~V}$ porovnaní s ostatnými mohylami jej venoval omnoho viac času - až osemnást' dní. ${ }^{47}$ Mal od nej vel'ké očakávania, ked’že spomedzi všetkých dovtedy preskúmaných mohýl mala najväčšie rozmery (priemer $16 \mathrm{~m}$, výška $180 \mathrm{~cm}$ ). ${ }^{48}$ Po odstránení násypu sa tu podarilo odokryt' veniec šiestich ohnísk, no bez známok po Pudských kostiach (pri jednom z ohnísk sa však nachádzalo obsidiánové jadro). Mohyla bola preto V. Budavárym interpretovaná ako kenotaf (Budinský-Krička 1967, 288). Podla vedúceho výskumu mala byt’ táto mohyla vztýčená

33 Nález vzácnej bronzovej spony v Krivokláte pri Púchove. Slovák, 21. august 1940, roč. 22, č. 198, s. 8.

Archív SAV, f. AÚ SAV - Vedecká činnost', zn. B V, inv. č. 200, č. j. 110/1940, škat. č. 21.

34 Zároveň tu však boli uložené takmer všetky nálezy z oblasti stredného Považia.

Archív SAV, f. AÚ SAV - Vedecká činnost', zn. B V, inv. č. 200, č. j. 110/1940, škat. č. 21.

35 Archív SAV, f. AÚ SAV - Rozpočet a systematizácia, zn. B X, inv. č. 461, č. j. 55/1941, škat. č. 81.

36 Archív SAV, f. AÚ SAV - Vedecká činnost', zn. B V, inv. č. 200, č. j. 124/1940, škat. č. 21.

Pôvodne plánoval V. Budaváry začat’ výskum už 8. júna.

Výskum tzv. východoslovenských mohýl bol spracovaný populárne-náučnou formou Pavlom Dvořákom v cykle kníh a televíznych dokumentov s názvom Stopy dávnej minulosti (kapitola v knihe sa nazýva „Kam vedú blatné cesty“; Dvoŕák. 2004).

Archív SAV, f. AÚ SAV - Vedecká činnost', zn. B V, inv. č. 200, č. j. 66/1940, škat. č. 21.

37 Skupinu 12 robotníkov stojacich na mohyle VII v Kožanoch zachytil V. Budaváry na fotografii, ktorú aj neskôr uverejnil (Budinský-Krička 1945-46, 283, obr. 11). V l'avej časti fotografie sa nachádzajú ešte minimálne d’alšie 4 osoby.

38 Archív SAV, f. AÚ SAV - Vedecká činnost', zn. B V, inv. č. 200, č. j. 124/1940, škat. č. 21.

Archív SAV, f. AÚ SAV - Vedecká činnost', zn. B V, inv. č. 200, č. j. 265/1940, škat. č. 21.

39 V štúdii venovanej východoslovenským mohylám z roku 1967 V. Budinský-Krička neoznačil na obr. 10 číslovanie mohýl. Z opisu ich lokalizácie v texte je zrejmé, že na ňom nie sú zaznačené všetky v texte spomínané mohyly prináležiace do katastrov obcí Kožany a Kurima (Budinský-Krička 1967, 282).

40 Všetky mohyly boli autorom výskumu podrobne opísané v štúdii uverejnenej v Slovenskej archeológii (Budinský-Krička 1967).

41 V štúdii z roku 1967 uviedol V. Budaváry v prípade mohyly II iné rozmery - priemer $11 \mathrm{~m}$, maximálna výška 1,2 m (Budinský-Krička 1967, 284).

42 Aj v tomto prípade V. Budaváry uviedol vo svojej neskoršej štúdii iné rozmery - priemer mohyly III mal byt' $11 \mathrm{~m}$ a výška $1,3 \mathrm{~m}$ (Budinský-Krička 1967, 284).

43 Archív SAV, f. AÚ SAV - Vedecká činnost', zn. B V, inv. č. 200, č. j. 171/1940, škat. č. 21.

Údaje uvedené v štúdii z roku 1967 sú viac-menej presné. Priemer je však udaný v rozmedzí 9,0 - 9,6 m (Budinský-Krička 1967, 284).

44 Rozmery v štúdii z roku 1967 boli trochu odlišné - priemer 10,2 - 10,4 m, výška asi 1m (Budinský-Krička 1967, 286).

45 Cenné archeologické vykopávky na východnom Slovensku. Slovák, 27. júl 1940, roč. 22, č. 176, s. 3.

46 Viktor Šemmer bol rovnako ako Bartolomej Krpelec menovaný v roku 1943 za tajomníka Štátneho archeologického ústavu (Neumann 2020).

47 Prvých 5 mohýl skúmal medzi 18. júnom a 10. júlom, mohylu VI skúmal od 11. do 29. júla.

Archív SAV, f. AÚ SAV - Vedecká činnost', zn. B V, inv. č. 200, č. j. 124/1940, škat. č. 21.

Archív SAV, f. AÚ SAV - Vedecká činnost', zn. B V, inv. č. 200, č. j. 171/1940, škat. č. 21.

48 Aj v tomto prípade sú rozmery v štúdii z roku 1967 odlišné - priemer 15,7 m, výška 175 cm (Budinský-Krička 1967, 288). 
pravdepodobne pre spoločensky významnejšieho človeka. Mal o tom svedčit' mohutný hlinený násyp s fragmentmi keramických nádob, štiepanou industriou a opracovaným kamenným „struhadlom“ zelenej farby. V. Budaváry pôvodne predpokladal, že tieto mohyly boli vztýčené v „,dobe hradištnej“. Na základe nálezov však prehodnotil ich datovanie na „najmladšiu dobu kamennú“ ${ }^{49} \mathrm{O}$ význame tohto nálezu nezabudol informovat’ aj MŠANO. ${ }^{50}$

Po doskúmaní šiestej mohyly sa výskum na niekol'ko týždňov zastavil. Príčinou boli problémy s financovaním. Už pri výskume mohyly $\mathrm{V}$ začali $\mathrm{V}$. Budavárymu dochádzat’ prostriedky na mzdy robotníkov. Rozhodol sa preto, že doskúmanie mohyly V ako i vel’mi sl’ubnej mohyly VI bude hradit' zo svojho platu a z honoráru za prednášky a cvičenia na univerzite. ${ }^{51}$ Po ich preskúmaní výkopové práce koncom júla ukončil. Začiatkom augusta však Župný úrad Šarišsko-zemplínskej župy slúbil pridelit’ na výskum v katastri Kožian sumu 4000 Ks. ${ }^{52}$ V. Budaváry túto ponuku, samozrejme, ochotne prijal a súčasne požiadal o poukázanie tejto sumy do 24. augusta, nakol'ko na nasledujúci deň chcel začal s prácou v teréne. ${ }^{53}$ Finančný príspevok od župného úradu však do uvedeného času nebol poukázaný na účet ústavu, v dôsledku čoho V. Budaváry požiadal MŠANO o pridelenie pravidelnej štátnej dotácie na 3. štvrt'rok. ${ }^{54}$ Župný úrad sa znova ohlásil až koncom septembra, kedy opätovne prislúbil uhradenie slúbeného príspevku. ${ }^{55}$ Stanovil si však podmienku, že všetky doteraz i v budúcnosti nájdené nálezy z výskumu mohýl budú uložené v plánovanom Šarišskom múzeu v Prešove. Ak by sa tak nestalo, župný výbor si vyhradzoval právo požadovat' udelený finančný príspevok spät'. Riaditel' ústavu informoval o tejto podmienke MŠANO. Jeho odpoved' riaditel'ovi ústavu bola jednoznačná - „výskumy, konané Vaším ústavom a nálezy pri týchto sa vyskytnuvšie, stávajú sa majetkom štátu. “Uloženie nálezov v múzeu, ktoré ešte neexistovalo, či dokonca priamo v budove župného úradu, bolo preto (aj z hl'adiska bezpečnosti) neprípustné ${ }^{56}$ Ministerstvo však vyriešilo neutešenú finančnú situáciu ústavu prv, než stihol dorazit’ príspevok od župného úradu. Pre výskumnú činnost' ústavu bolo začiatkom októbra uvol’nených $10000 \mathrm{Ks}$, k čomu sa koncom mesiaca prirátala posledná štvrt'ročná štátna dotácia vo výške $2465 \mathrm{Ks} .^{57}$ Tým sa uvol’nila cesta pre d’alšie terénne aktivity. Príspevok od župného úradu bol na účet ústavu prevedený až 26. októbra. ${ }^{58}$

Počas výskumu v Kožanoch a Kurime podnikal V. Budaváry pravdepodobne menšie výskumné „expedície“ po okolí. Svedčí o tom skutočnost', že v liste pre MŠANO z 12. júla spomenul, že doteraz našiel aj d’alšie mohyly v katastri Okruhlého a Šapinca (okr. Svidník), ktoré pokladal za súčasné s tými, ktoré práve skúmal v Kožanoch a Kurime..$^{59}$ Počas jedného z prieskumov, na ktorom ho sprevádzal Juraj Ivanka, objavil v katastri Šapinca sedem nových mohýl ${ }^{60}$ - tri na poli, tri na pasienku a jednu na hrebeni vrchu Košariska na hranici štefurovského a šapinského katastra. ${ }^{11} \mathrm{O}$ svojom náleze informoval aj MŠANO, ktoré dalo súhlas s ich výskumom. ${ }^{62}$ Počas výskumu mohyly VI v Kurime prezrel V. Budaváry na upozornenie K. Seredayho aj vrchy Stavenec a Krivárske pri Giraltovciach. Aj

49 Objavili pät' tisíc rokov staré pohrebište. Slovák, 12. júl 1940, roč. 22, č. 162, s. 7.

50 Archív SAV, f. AÚ SAV - Vedecká činnost', zn. B V, inv. č. 200, č. j. 124/1940, škat. č. 21.

51 Z vyúčtovania Štátneho archeologického ústavu za rok 1940 sa dá vyčítat’, že V. Budaváry prispel na výskum čiastkou 3276,80 Ks. „Pôžičku“ poskytol ústavu dňa 20. júla, vrátená mu bola 26. októbra toho istého roku.

Archív SAV, f. AÚ SAV - Vedecká činnost', zn. B V, inv. č. 200, č. j. 171/1940, škat. č. 21.

Archív SAV, f. AÚ SAV - Rozpočet a systematizácia, zn. B X, inv. č. 461, č. j. 55/1941, škat. č. 81.

52 Archív SAV, f. AÚ SAV - Rozpočet a systematizácia, zn. B X, inv. č. 460, č. j. 152/1940, škat. č. 81.

53 Archív SAV, f. AÚ SAV - Rozpočet a systematizácia, zn. B X, inv. č. 460, č. j. 152/1940, škat. č. 81.

$\mathrm{V}$ liste adresovanom Ministerstvu školstva a národnej osvety informoval V. Budaváry o svojich pracovných plánoch na nasledujúce mesiace - od 26. augusta do 15. septembra plánoval pokračovat’ vo výskume v Kožanoch a Kurime, v termíne od 1. do 10. októbra chcel podniknút' výskumy vo Veselom a čas od 14. do 19. októbra hodlal strávit' výskumom v Diviakoch nad Nitricou.

Archív SAV, f. AÚ SAV - Vedecká činnost', zn. B V, inv. č. 200, č. j. 166/1940, škat. č. 21.

54 Archív SAV, f. AÚ SAV - Rozpočet a systematizácia, zn. B X, inv. č. 460, č. j. 175/1940, škat. č. 81.

55 Archív SAV, f. AÚ SAV - Rozpočet a systematizácia, zn. B X, inv. č. 460, č. j. 225/1940, škat. č. 81.

56 Archív SAV, f. AÚ SAV - Vedecká činnost', zn. B V, inv. č. 200, č. j. 242/1940, škat. č. 21.

57 Archív SAV, f. AÚ SAV - Rozpočet a systematizácia, zn. B X, inv. č. 460, č. j. 302/1940, škat. č. 81

Archív SAV, f. AÚ SAV - Rozpočet a systematizácia, zn. B X, inv. č. 460, č. j. 334/1940, škat. č. 81.

58 Archív SAV, f. AÚ SAV - Rozpočet a systematizácia, zn. B X, inv. č. 461, č. j. 55/1941, škat. č. 81.

59 Archív SAV, f. AÚ SAV - Vedecká činnost', zn. B V, inv. č. 200, č. j. 124/1940, škat. č. 21.

60 Neskôr k nim pribudli ešte d'alšie dve (Budinský-Krička 1945-46, 289).

61 Juraj Ivanka bol s vel'kou pravdepodobnost’ou jedným z kožianskych robotníkov, ktorí sa priamo zúčastňovali výskumu mohýl. Naznačuje to V. Budinský-Krička v texte z roku 1967, ktorý sa venuje mohylám v Šapinci: „Autora upozornili na ne robotníci pri výskume mohýl v susednom kožianskom a kurimskom chotári.“ (Budinský-Krička 1945-46, 289)

Archív SAV, f. AÚ SAV - Vedecká činnost', zn. B V, inv. č. 200, č. j. 155/1940, škat. č. 21.

62 Archív SAV, f. AÚ SAV - Vedecká činnost', zn. B V, inv. č. 200, č. j. 173/1940, škat. č. 21. 
tu objavil niekol'ko mohýl, ktoré sa koncentrovali do skupín. V prvej skupine bolo šest’ mohýl, v ostatných dvoch po sedem mohýl. ${ }^{63} \mathrm{O}$ pár dní neskôr informoval o svojom objave Okresný úrad v Giraltovciach a žiadal o ochranu nájdených mohylových násypov. Zároveň naznačil, že plánuje zaradit’ ich výskum do programu Štátneho archeologického ústavu na rok $1941 .{ }^{64}$

Vd’aka nedostatku financií boli v auguste d'alšie terénne aktivity Štátneho archeologického ústavu prerušené. Jedinú výnimku predstavovala návšteva Mikušoviec (okr. Ilava), kde riaditel’ ústavu na základe „kopcov“ ako i nálezov uložených v miestnej škole predpokladal prítomnost” pohrebiska. ${ }^{65}$ Do Mikušoviec zavítal 29. augusta. Okrem „kopcov“ navštívil tiež polohu Skalice, vypínajúcu sa nad obcou, kde identifikoval prítomnost’ sídliska „s halštatskou keramikou staršieho rázu“ (Budinský-Krička 1945-46, 263; Budinský-Krička 1993, 299). ${ }^{66}$

Počas obdobia útlmu terénnych aktivít mal riaditel’ ústavu čas a priestor na spracovávanie nálezov z výskumu na východnom Slovensku. Jeho aktivity, realizované predovšetkým v Slovenskom národnom múzeu, občas spestrovali väčšie či menšie zásielky s nálezmi či hlásenia o objavených pamiatkach. Jednou z nich bola zásielka od stavebnej správy slovenských železníc v Prešove, ktorú V. Budavárymu doručili začiatkom augusta. Zásielka obsahovala fosílne kosti, fragment stoličky a zlomky kostí mamuta. Súbor nálezov bol nájdený pri stavbe železnice pri Vranovskom Dlhom (okr. Vranov nad Topl'ou), a to v híbke $12 \mathrm{~m}$ pri železničnom kilometri II. 6/7.67 Výkopové práce boli súčast’ou vel'kého stavebného projektu - výstavby približne 50-kilometrového úseku železnice, ktorá mala spájat' Strážske s Prešovom. Od júna 1939 tu bolo nasadených vyše 6000 robotníkov, ktorí pracovali zároveň na viacerých úsekoch. ${ }^{68}$ Nebolo to však poslednýkrát, čo sa stavebná správa železníc ozvala V. Budavárymu s nečakaným nálezom. Ďalší pozoruhodný nález bol totiž objavený o niekolko mesiacov neskôr.

\section{Jeseň - práca a oddych}

Počas augusta a septembra realizoval ústav len jeden krátkodobý výskum v katastri obce Veselé (okr. Piešt’any). Miestny obyvatel' menom Celestín Kolarovič totiž ešte v roku 1939 počas sadenia ovocných stromov na poli svojej matky objavil niekol'ko inhumačných hrobov (Budaváry 1940, 79). Prvé dva hroby, ktoré našiel, rozrušil, po náleze tretieho sa rozhodol na svoj nález upozornit' Slovenské národné múzeum. Tomu so správou o objavení hrobov zaslal zároveň keramickú šálku zdobenú šnúrovou výzdobou spoločne s d’alšou misou. V. Budaváry prišiel do Veselého až 11. septembra $1940 \mathrm{~s}$ ciel’om podniknút’ tu menšiu zist'ovaciu „,vykopávku“. ${ }^{69} \mathrm{~V}$ nevel’kej sonde sa mu podarilo objavit' dva hroby so skrčenými l’udskými skeletmi. $V$ prvom z nich, kde ležala kostra na pravom boku s hlavou smerom na západ, bola nájdená len jedna šálka. Druhý hrob bol svojou výbavou pre svojho objavitel’a ovel’a atraktívnejší. Pri l’udskej kostre, ležiacej v rovnakej polohe ako v predchádzajúcom prípade, bola uložená keramická šálka zdobená odtlačkami šnúry, triangulárny kamenný hrot, kostený hrot „oštepu“ a zvieracie kosti (autorom výskumu identifikované ako medvedie). V. Budaváry pravdepodobne považoval nález hrobu „lovca“, ako ho interpretoval, za vel’mi významný. ${ }^{70}$ Nasvedčuje tomu i skutočnost', že ho nechal vyzdvihnút' in situ a preniest' do Slovenského národného múzea, kde bol následne vystavený (obr. 2). Novinová správa o výskume sa objavila krátko po jeho ukončení. ${ }^{71}$ Bolo

\footnotetext{
63 Archív SAV, f. AÚ SAV - Vedecká činnost', zn. B V, inv. č. 200, č. j. 156/1940, škat. č. 21.

64 Archív SAV, f. AÚ SAV - Spolupráca s inštitúciami, zn. B VII, inv. č. 269, č. j. 156/1940, škat. č. 55.

65 Jeden z „kopcov“ (mohyla 4) preskúmala Z. Pivovarová v rámci výskumu pohrebísk lužickej kultúry v katastri Mikušoviec v rokoch 1961 - 1963 (Pivovarová 1965a, 112).

66 Na lokalite Skalice neprebehol doteraz okrem prieskumu z roku 1940 (a tiež neskorších prieskumov) žiadny archeologický výskum. Identifikované výšinné sídlisko napriek tomu Z. Pivovarová označila za jedno z najvýznamnejších svojho druhu v rámci lužickej kultúry na Slovensku (Pivovarová 1965b, 483). M. Horňák ho na základe rozlohy (22 ha) ako i vlastných terénnych prieskumov označil za centrálne hradisko (Horñák 2016, 472).

67 Archív SAV, f. AÚ SAV - Vedecká činnost', zn. B V, inv. č. 200, č. j. 126/1940, škat. č. 21.

68 Vyše 6000 robotníkov na stavbe novej železnice Strážske - Vranov - Prešov. Slovák, 26. jún 1940, roč. 22, č. 149 , s. 4.

69 V správe uverejnenej v Časopise MSS je trvanie „vykopávky“ určené dňami 11. - 12. septembra. V súhrnnej správe o výskume pohrebiska vo Veselom z roku 1965 uviedol autor ako dobu uskutočnenia výskumu 11. - 13. september 1940 (Budaváry 1940, 79; Budinský-Krička 1965, 55).

70 Svedčí o tom aj text novinovej správy z 21. septembra 1940, kde je v prípade tohto hrobu uvedené, že ide o nález „mimoriadneho významu“.

Pri Piešt’anoch objavili rozsiahle pohrebište z doby bronzovej. Slovák, 21. september 1940, roč. 22, č. 225 , s. 2.

71 Pri Piešt’anoch objavili rozsiahle pohrebište z doby bronzovej. Slovák, 21. september 1940, roč. 22, č. 225 , s. 2.

Ako zaujímavost' možno uviest', že meno V. Budaváryho sa v novinovej správe uvádza v tvare „Budelán“.
} 
v nej uvedené, že vo výskume „rozsiahleho pohrebišt’a“ sa plánuje pokračovat' aj d'alej. ${ }^{72}$ Za týmto účelom boli vykonané opatrenia, ktoré mali zamedzit' ničeniu tejto lokality. ${ }^{73}$

Ďalší výjazd do terénu vyvolali výkopové práce v Nitre a jej okolí. Začiatkom októbra sa pri kladení tepelného vedenia $\mathrm{v}$ areáli štátnej nemocnice $\mathrm{v}$ Nitre (okr. Nitra) narazilo na niekol'ko l’udských kostier. ${ }^{74}$ Ležali približne $\mathrm{v}$ hĺbke $120 \mathrm{~cm}$ a pri lebkách mali uložené zle vypálené keramické nádoby, v ktorých robotníci našli čierny popol. Hoci približne polovicu všetkých nálezov zničili, zvyšná čast' bola uložená u riaditel’a nemocnice dr. Jozefa Závodného. ${ }^{75}$ Správa o hroboch sa rýchlo dostala do dennej tlače. Miesto nálezu bolo preto prezreté správcom Štátneho múzea v Nitre Karvašom, ktorý následne privolal V. Budaváryho. Po jeho príchode mu riaditel' nemocnice odovzdal jednu zo zachránených keramických nádob. ${ }^{76} \mathrm{Aj}$ vd'aka nej zaradil nálezy kostier $z$ hrobov do obdobia 8. - 9. storočia. ${ }^{77}$ Hroby z rovnakého obdobia už boli v Nitre známe. Podarilo sa ich nájst' pri stavbe vojenskej nemocnice a $\mathrm{v}$ predchádzajúcom roku aj pri kanalizačných prácach na Kapitulskej ulici. $\mathrm{V}$ liste adresovanom Ministerstvu školstva a národnej osvety zhodnotil V. Budaváry potenciál novo nájdeného pohrebiska týmito slovami: „Ak by bola možnost’ ho sústavne prebádat', mohlo by nás poučit' o hmotnej kultúre a o telesnej stránke (zachovaný antropologický materiál) staroslovenských obyvatel’ov Nitry.“ Ďalší výskum tu preto pre ústav naplánoval už na nasledujúci rok. ${ }^{78}$

Prítomnost' V. Budaváryho si vyžiadali terénne zásahy severne od Nitry. V priebehu roka 1940 tu bola rekonštruovaná železničná trat' medzi Zbehmi a Leopoldovom. Na prácach sa zúčastňovalo niekol'ko stoviek robotníkov, ktorých ciel’om bolo vyrovnávat' ostré zákruty. ${ }^{79}$ Za týmto účelom bolo na niektorých miestach nutné vyhíbit' do terénu zárezy. Takto bolo upravené aj úpätie výbežkov južne od Andačského potoka v katastri rovnomennej obce. Vd’aka týmto terénnym zásahom bolo severne od obce Andač (okr. Nitra) v polohe Basa ${ }^{80}$ porušené rozsiahlejšie pohrebisko. Vedenie stavby však o náleze

\footnotetext{
72 V. Budaváry sa do Veselého vrátil už nasledujúci rok (Prehl’ad prác 1941, 54).

73 Pohrebisko objavené V. Budavárym sa stalo vôbec prvou lokalitou kultúry Chłopice - Veselé na Slovensku. Táto kultúra však získala svoj terajší názov až začiatkom 60. rokov 20. storočia (Furmánek - Veliačik - Vladár 1991, 49; Bátora 2018, 71).

74 V Nitre našli vel'ké pohrebište. Slovák, 9. október 1940, roč. 22, č. 240, s. 4.

75 Meno riaditel'a nemocnice sa v tlači uvádza ako J. Závodský, V. Budaváry ho v korešpondencii nazýva ako J. Závodný. V tejto práci budeme používat’ formu Závodný.

V Nitre našli vel’ké pohrebište. Slovák, 9. október 1940, roč. 22, č. 240, s. 4.

76 Archív SAV, f. AÚ SAV - Vedecká činnost', zn. B V, inv. č. 200, č. j. 327/1940, škat. č. 21.

77 Skelety boli vo všetkých 5 hroboch orientované hlavou na západ, híbka hrobovej jamy bola medzi $80-100 \mathrm{~cm}$. Staroslovenské pohrebište pri Nitre. Slovák, 26. október 1940, roč. 22, č. 255, s. 4.

Archív SAV, f. AÚ SAV - Vedecká činnost', zn. B V, inv. č. 200, č. j. 249/1940, škat. č. 21.

78 Archív SAV, f. AÚ SAV - Vedecká činnost', zn. B V, inv. č. 200, č. j. 249/1940, škat. č. 21.

79 Rekonštrukčné práce na železničnej trati Zbehy-Leopoldov. Slovák, 12. september 1940, roč. 22, č. 217 , s. 5.

80 Uvedená poloha ležala medzi kilometrami 5,9 - 6,0 železničnej trate Zbehy-Leopoldov (Kudláček 1953, 199).
} 


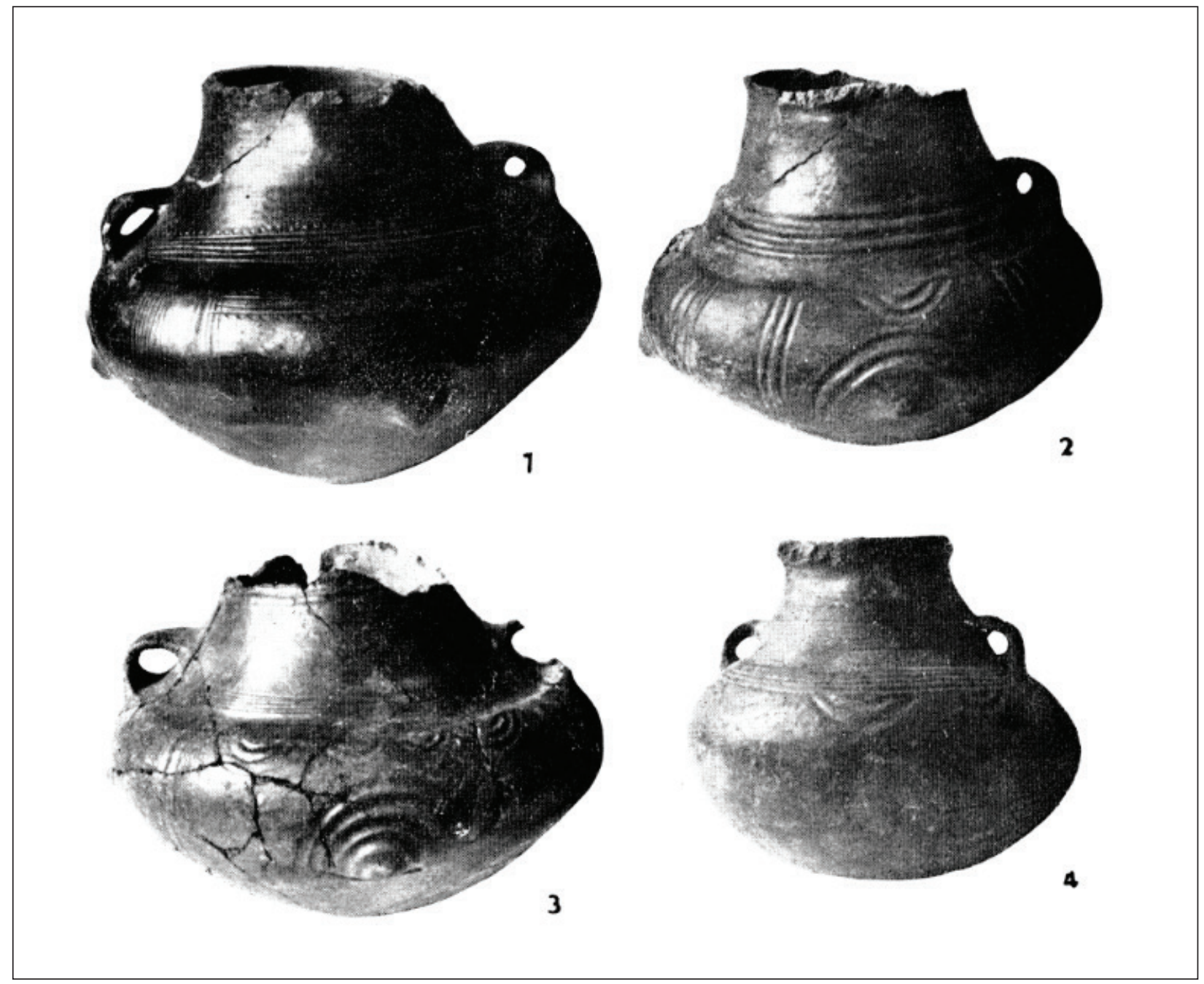

Obr. 3. Keramické nádoby objavené v rozrušených hroboch počas rekonštrukcie trate v katastri obce Andač (podl’a Kudláček 1953, tab. 1).

Fig. 3. Ceramic vessels found in disturbed graves during railway reconstruction in the cadastre of Andač (after Kudláček 1953, tab. 1).

vôbec neupovedomilo príslušné miesta. Niektoré z urien, ktoré tu v priebehu októbra nachádzali železniční robotníci, boli posielané do Trnavy. ${ }^{81}$ Okrem urnových hrobov sa tu podarilo objavit' aj inhumačné hroby, v ktorých výbave sa podl’a svedectva vedúceho úseku P. Vindiša nachádzali aj bronzové „kruhy“ (Kudláček 1953, 199). O náleze sa vd’aka snímkam nájdených urien dozvedel správca Štátneho múzea v Nitre Karvaš, ktorý sa o deň neskôr dostavil na obhliadku miesta spolu s V. Budavárym. ${ }^{82} \mathrm{Na}$ základe železných a bronzových nálezov z urien datoval V. Budaváry birituálne pohrebisko do „prvej doby železnej“ (obr. 3), konkrétne do obdobia kultúry „skýto-hallštatskej““ ${ }^{83}$ Archeologické nálezy boli získané aj pri d’alšom záreze rekonštruovanej trate západne od obce pri Alekšinských rybníkoch. ${ }^{84}$ Tie sa však už podarilo zachránit’ Ing. Štefanovi Janšákovi.

V októbri sa V. Budaváry zúčastnil aj pomerne kurióznej a nezvyčajnej udalosti - exhumácie údajného hrobu Janka Krála v Zlatých Moravciach (okr. Zlaté Moravce). Iniciátorom celej akcie bol tajomník Matice slovenskej dr. Stanislav Mečiar. Uprostred zlatomoraveckého cintorína nechal vykopat' niekol'ko hrobov, kde jeden z nich bol

81 Nie je známe, kto bol v Trnave prijímatelom zaslaných urien.

Pri Andači našli starobylé pohrebište. Slovák, 23. október 1940, roč. 22, č. 252, s. 4.

82 Návšteva stavby železničnej trate v katastri Andača sa s vel'kou pravdepodobnost’ou odohrala v krátkom časovom slede pred alebo po kontrole výkopu tepelného vedenia $\mathrm{v}$ areáli štátnej nemocnice $\mathrm{v}$ Nitre.

83 Pri Andači našli starobylé pohrebište. Slovák, 23. október 1940, roč. 22, č. 252, s. 4.

84 Išlo o kilometre 8,0 - 8,1 železničnej trate Zbehy-Leopoldov (Kudláček 1953, 199). 
na základe zachovaného „čierneho hodvábu, básnickej kravaty a iných charakteristických pozostatkov“ identifikovaný ako hrob Janka Král'a. ${ }^{85}$ Svoje dobrozdanie pripojili okrem V. Budaváryho aj d’alší odborníci - univ. prof. Jozef Babor, dr. Matej Štepita a dr. Jozef Cincík. ${ }^{86}$ Následne bol na nedel’u 3. novembra pripravený slávnostný prevoz ostatkov na Národný cintorín do Turčianskeho Sv. Martina. ${ }^{87}$ Celý sprievod sa však premenil na propagandistickú prorežimnú akciu (obr. 4$){ }^{88}$

Druhú polovicu októbra plánoval riaditel' ústavu strávit' na dovolenke. Nevedno, ako ju plánoval využit' - isté je len to, že počas nej si osobne prezrel viaceré lokality v povodí Nitrice. ${ }^{89} \mathrm{Z}$ katastra Diviak nad Nitricou (okr. Prievidza) boli totiž už dávnejšie získané fragmenty keramických nádob, ktoré boli nájdené v polohe Vikárka pri kopaní jamy na uskladnenie l'adu (Budinský-Krička 1962, 124)..$^{90} \mathrm{Na}$ upozornenie štátneho učitel'a Jána Vojtylu ${ }^{91}$ vyrazil V. Budaváry v októbri na spomenuté miesto, aby overil prítomnost' d’alších nálezov. ${ }^{92} \mathrm{Na}$ cestu do Diviak nad Nitricou vyrazil ráno 21. októbra. ${ }^{93}$ Jeho ciel'om však bolo viacero lokalít, ktoré hned' po svojom príchode navštívil. Prvou bolo nálezisko keramických nádob v polohe Vikárka na poli Štefana Ďurču, d’alej vel'ký umelý kužel'ovitý násyp v polohe Bukovec a napokon výkopy v Diviackej Novej Vsi (okr. Prievidza), kde boli pri stavbe domov nájdené pamiatky

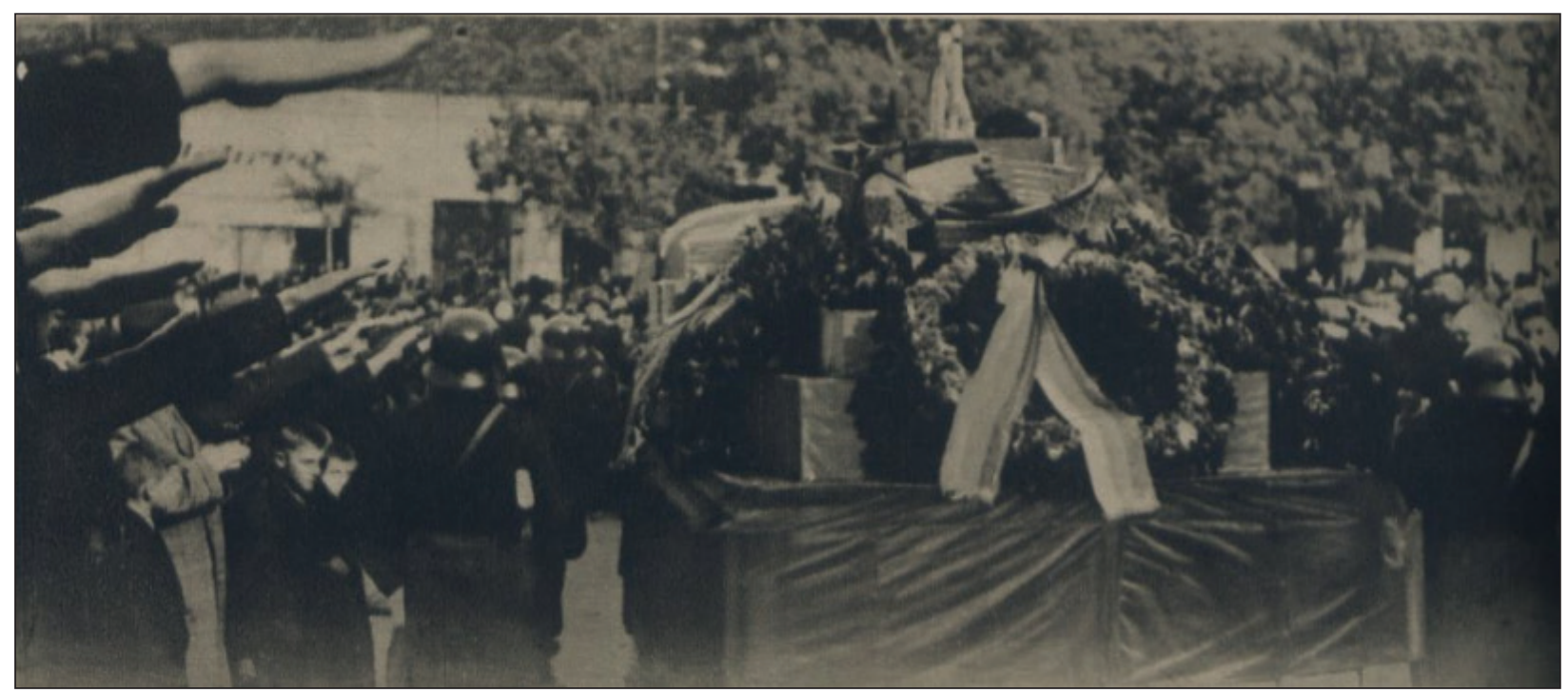

Obr. 4. Prevoz ostatkov Janka Král’a na aute zo Zlatých Moraviec (Nový svet, 9. november 1940, č. 45, s. 2).

Fig. 4. 'Transporting of human remains of Janko Král' on car from Zlaté Moravce (Nový svet, 9. november 1940 , č. 45 , s. 2 ).

85 Našli hrob básnika Janka Krála. Slovák, 16. október 1940, roč. 22, č. 246, s. 7.

86 Telesné pozostatky Janka Krála prevezú na cintorín do Turčianskeho Sv. Martina. Slovák, 22. október 1940, roč. 22 , č. 251 , s. 3.

87 Telesné pozostatky Janka Král’a prevezú do Turčianskeho Sv. Martina. Slovák, 30. október 1940, roč. 22, č. 258 , s. 2.

88 Na básnikovu rakvu prišiel do Zlatých Moraviec položit' veniec minister vnútra Alexander Mach. Účast' V. Budaváryho priamo na sprievode nie je potvrdená.

Prevezenie pozostatkov Janka Král'a. Slovák, 3. november 1940, roč. 22, č. 261, s. 10.

Prevezenie pozostatkov Janka Král’a zo Zlatých Moraviec do martinského národného cintorína. Slovák, 5. november 1940, roč. 22 , č. 262 , s. 2.

Z minulých dní. Nový svet, 9. november 1940, roč. 15, č. 45, s. 2.

89 Dňa 19. augusta informoval V. Budaváry Ministerstvo školstva a národnej osvety o termíne svojej dovolenky. Tú mal čerpat' od 16. do 30. septembra a od 20. do 31. októbra. Druhý termín koliduje s prieskumom v povodí Nitrice a so začiatkom výskumu v Šapinci.

Archív SAV, f. AÚ SAV - Vedecká činnost', zn. B V, inv. č. 200, č. j. 166/1940, škat. č. 21.

90 Nálezy boli robotníkmi, ktorí ich našli, zničené.

Objav popolnicového pola v Diviakoch nad Nitricou. Gardista, 28. november 1940, roč. 2, č. 66, s. 5

91 Ján Voltyla bol príbuzným Karola Wojtyłu, neskoršieho pápeža Jána Pavla II.

Stručný prierez históriou obce. Diviacke noviny, júl 2010, č. 2, s. 4.

92 Majitelom pozemku bol Štefan Ďurčo.

Objav popolnicového pol'a v Diviakoch nad Nitricou. Gardista, 28. november 1940, roč. 2, č. 66, s. 5.

93 Vd’aka zachovanej prílohe k cestovnému účtu sa dá presne zrekonštruovat' cestovný plán V. Budaváryho. V uvedený deň (21. október) nastúpil v Turčianskom Sv. Martine o 7:13 na rýchlik. V Hornej Štubni presadol o 9:33 na motorový vlak do Prievidze, kam dorazil o 10:35. Odtial'to pokračoval autobusom (odchod o 14:30) do Diviak nad Nitricou, kam prišiel o 15:30.

Archív SAV, f. AÚ SAV - Vedecká činnost', zn. B V, inv. č. 200, č. j. 282/1940, škat. č. 21. 
z doby vel'komoravskej. Nasledujúci deň otvoril hned’ ráno pokusnú sondu na poli Š. Ďurču, kde spolu so Štefanom Tkáčom ${ }^{94}$ a d’alšími pomocníkmi odokryl štyri žiarové hroby. ${ }^{95}$ Urny nájdené v hroboch obsahovali nedopálené ludské pozostatky. ${ }^{96}$ Medzi nimi sa nachádzali bronzové ihlice, fragment bronzového noža s prelamovanou rukovät’ou a zlomok šálky. Žiarové hroby podl’a úsudku V. Budaváryho tvorili súčast’ väčšieho pohrebiska, ktoré datoval do „okruhu popolnicových polí mladolužického typu“, teda do neskorej doby bronzovej. V. Budaváry vyjadril úmysel pokračovat’ vo výskume nasledujúci rok. ${ }^{97}$ Nasledujúci deň bola sonda ráno zasypaná a V. Budaváry odcestoval do Diviackej Novej Vsi, kde s negatívnym výsledkom „sondoval“ v záhrade miestneho obyvatel’a Štefana Koša. ${ }^{98}$ Na upozornenie učitel’a Štefana Andrisa zašiel aj do údolia „Priepast““, kde pod sterilnou vrstvou naplavenín objavil až $50 \mathrm{~cm}$ hrubú kultúrnu vrstvu datovanú na základe keramických zlomkov do „staršej doby hallštattskej““ ${ }^{99}$ Dňa 24. októbra sa V. Budaváry vrátil spät’ do Diviakov nad Nitricou a venoval sa zameriavaniu umelého násypu v polohe Bukovec. ${ }^{100}$ Predmety vo vrstve na temene tohto kopca ho presvedčili, že nejde o mohylu, ale o malú pevnôstku z 11. - 12. storočia. ${ }^{101}$ Následne sa pobral do Ješkovej Vsi (okr. Prievidza), kde ho istý pán Šmotlák ${ }^{102}$ a spomínaný učitel' J. Vojtyla upozornili na neznámy kopec. Po jeho prehliadnutí V. Budaváry skonštatoval, že ide o doposial' neznámu mohylu s priemerom $20 \mathrm{~m}$, ktorá však už bola v minulosti porušená. Bližšie datovanie nebolo v tej chvíli možné. ${ }^{103}$

Po uplynutí dovolenky zamýšl'al riaditel' ústavu znova sa vrátit’ na východné Slovensko, kde jeho letné výkopové práce prerušil nedostatok financií. Začiatok výskumu v Šapinci (okr. Svidník) naplánoval na 28. október. O svojom úmysle informoval miestny obecný úrad a pridal ponuku na 4 pracovné miesta pre robotníkov. Ostatných „zapracovaných“ mužov si chcel priviest’ zo susedných Kožian. ${ }^{104}$ Začiatok výskumu sa oneskoril oproti pôvodnému plánu o dva dni. ${ }^{105}$ Hned' v prvej mohyle (priemer 12 m, výška 1,2 m) sa podaril mimoriadny nález (Budinský-Krička 1967, 289-292). Okrem keramických fragmentov, kamennej štiepanej industrie, kalcinovaných kostí a zlomku praslena tu bol vôbec prvýkrát v rámci výskumu neskoroeneolitických mohýl na východnom Slovensku objavený zachovaný kostrový hrob (obr. 5). Jedinec ležal v oválnej hrobovej jame zahíbenej do terénu, na lavom boku v smere SZ - JV. Výskum prvej mohyly trval celý týždeň (do 6. novembra). Následne sa pustil do výskumu ned’alekej mohyly II, ktorú so svojimi robotníkmi preskúmal v priebehu 7. a 8. novembra. ${ }^{106}$ Hoci sa tu už nepodarilo nájst’ podobnú hrobovú jamu, z násypu mohyly bolo získané „vel’mi pekne spracované kamenné struhadlo, iné štiepané nástroje kamenné a brúsená sekerka kamenná“. Posledná tretia mohyla s priemerom až $14 \mathrm{~m}$ bol najväčšou spomedzi všetkých troch skúmaných mohýl (Budinskýy-Krička 1967, 294). Aj tu sa podarilo objavit’ len zlomky keramiky, kamenné úštepy a kal-

94 Istý Š. Tkáč sa spomína aj v súvislosti s výskumom v Diviakoch nad Nitricou v polovici 70. rokov. Vtedajší výskum bol realizovaný na parcele ned'aleko jeho domu (Veliačik 1991, 143).

95 Vo vyúčtovaní výdavkov Štátneho archeologického ústavu za rok 1940 je účtovaná mzda pre Štefana Tkáča, ktorý dostal za vykonanú prácu mzdu 30 Ks. S určitost'ou sa na výskume zúčastnili aj d’alšie osoby, ako tomu napovedá spomenuté vyúčtovanie. Títo zamestnanci (mená ani počet nie sú známe) dostali dovedna mzdu 300 Ks. O väčšom počte osôb svedčí i vel'kost’ sondy - 2,5 x 15 m (Budinský-Krička 1962, 124).

Archív SAV, f. AÚ SAV - Rozpočet a systematizácia, zn. B X, inv. č. 461, č. j. 55/1941, škat. č. 81.

96 V prílohe k cestovnému účtu z Diviak nad Nitricou sa spomínajú len 4 žiarové hroby. V štúdii V. Budinského-Kričku z roku 1962 je však uvedených až 5 hrobov (rovnako aj na náčrte; Budinský-Krička 1962, 123-124). Ako zaujímavost' uved'me, že fotografia jednej urny z objavených žiarových hrobov bola publikovaná už v roku 1942 v krátkej práci V. Budaváryho Výtvarný prejav slovenského praveku (Budaváry 1942, obr. 14). Ide o urnu z hrobu č. 4, ktorá je publikovaná aj v roku 1962 (Budinský-Krickea 1962, 126). Autorom fotografie bol Peter Mendel zo Slovenského národného múzea.

97 Objav popolnicového pol’a v Diviakoch nad Nitricou. Gardista, 28. november 1940, roč. 2, č. 66, s. 5.

Archeologický výskum tu v roku 1957 podnikla Z. Pivovarová (Pivovarová 1959). Aj v neskoršom období bolo pohrebisko čiastočne narúšané, no viaceré nálezy z jednotlivých hrobov sa podarilo zachránit' (Šuhajíková-Pivovarová 1961; Ruttkay 1965, 192-193). Vel'koplošný záchranný výskum tu v polovici 70. rokov podnikol L. Veliačik (Veliaǔik 1975, 110-112; 1976, 210-213; 1991).

98 Menšiu sondáž uskutočnil V. Budaváry v blízkosti miesta, kde boli predtým údajne nájdené 3 kostrové hroby (Bialeková 1992a, 105).

99 Archív SAV, f. AÚ SAV - Vedecká činnost', zn. B V, inv. č. 200, č. j. 282/1940, škat. č. 21.

100 Názov polohy sa udáva aj ako Bükkös alebo Mŕtvy vrch. Nachádza sa medzi obcami Diviaky nad Nitricou a Ješkovou Vsou nad Nitricou, na západnej strane cesty medzi oboma obcami.

101 D. Bialeková uvažuje v prípade umelého násypu v polohe Bukovec o mohyle z 9. - 10. storočia (Bialeková 1992b, 105).

102 V neskorších prácach sa uvádza v tvare Šmatlák (Bialeková 1992c, 106).

103 Amatérske výkopy sa na spomínanom kopci realizovali už pred 1. svetovou vojnou, kedy tu bol údajne objavený detský hrob a d’alšie sprievodné nálezy (Bialeková 1992c, 106). V súčasnosti sa „kopec“ považuje za zvyšok stredovekého hrádku stotožneného s tzv. Tristanovou vežou. Jej majitel’mi mali byt' na prelome 13. - 14. storočia synovia Tristana z rodu Diviackovcov (Marek 2010, 17; Hrubý 2014, 45).

104 Archív SAV, f. AÚ SAV - Vedecká činnost', zn. B V, inv. č. 200, č. j. 265/1940, škat. č. 21.

105 Archív SAV, f. AÚ SAV - Vedecká činnost', zn. B V, inv. č. 200, č. j. 313/1940, škat. č. 21.

106 Archív SAV, f. AÚ SAV - Vedecká činnost', zn. B V, inv. č. 200, č. j. 313/1940, škat. č. 21. 


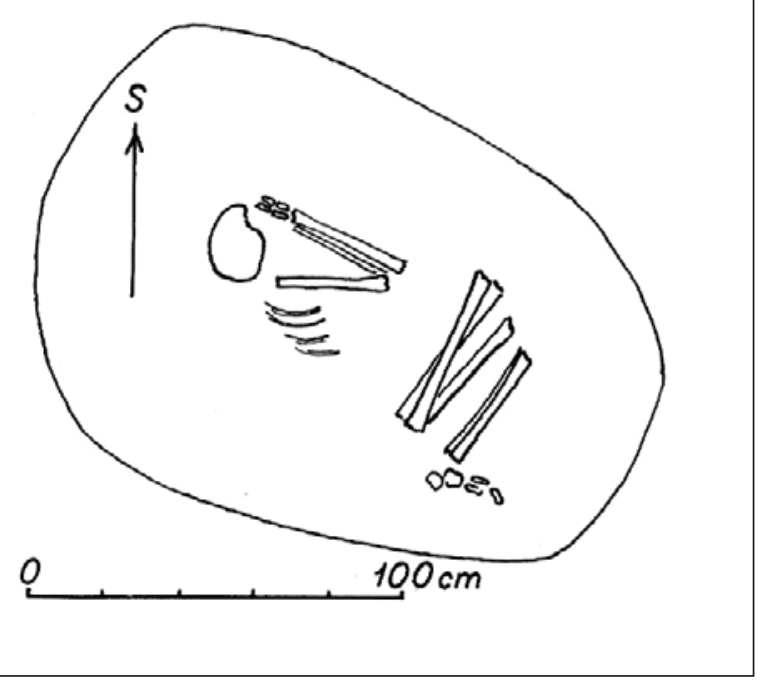

Obr. 5. Hrob pod mohylou 1 v Šapinci (podl'a Budinsky-Krička 1967, obr. 17).

Fig. 5. Grave under the barrow No. 1 in Šapinec (after Budinský-Krička 1967, obr. 17). cinované kosti. Terénne práce na mohyle trvali v tomto prípade až pät' dní (11. - 15. november). ${ }^{107}$ Nasledujúci deň bol venovaný úprave terénu do pôvodného stavu - V. Budaváry sa totiž musel pripravit' na odchod do Bratislavy, kde musel pokračovat' s vedením prednášok a seminárov na univerzite. Rovnako ako v lete, aj teraz podnikal riaditel' ústavu menšie výskumné „exkurzie“ po okolí. V priebehu výskumu v Šapinci sa mu takýmto spôsobom podarilo vd'aka upozorneniu Jozefa Zicha identifikovat' v ned'alekej obci Marhaň (okr. Bardejov) 13 dovtedy neznámych mohýl. Ležali na horskom hrebeni medzi kótami 307 a 304 a tak ako mnohé predchádzajúce mohyly, aj tieto boli poškodené zákopmi z 1 . svetovej vojny. ${ }^{108}$

\section{Zima - čas na odpočinok?}

Mohlo by sa zdat', že uzatvorením výskumu v Šapinci sa terénne aktivity ústavu na tento rok skončili. Nebolo tomu však tak. Na východné Slovensko sa

V. Budaváry opät' vrátil ešte 2. decembra, kedy pokračoval vo výskume mohýl VII a VIII v Kožanoch. Prvá z mohýl, nachádzajúca sa pod polohou „Lazy“, bola porušená cestou medzi Kožanmi a Šapincom. V mohylovom násype, ktorý dosahoval priemer až $12 \mathrm{~m}$, boli objavené stopy po ohni, niekol'ko kamenných nástrojov a zvyšky kalcinovaných kostí (Budinský-Krička 1967, 284-285). ${ }^{109}$ Nálezová situácia v mohyle VIII bola vel'mi podobná. Pozornost’ pútala najmä kamenná sekerka z rádiolaritu (Budinský-Krička 1967, 285-286). Počas výskumu týchto mohýl stihol V. Budaváry opät' overit' prítomnost' aj d'alších mohylových útvarov, na ktoré ho v katastri obce Okruhlé (okr. Svidník) upozornil Andrej Škvarek. Na južnom svahu vrchu Stavenec sa mu naozaj podarilo objavit' štyri mohyly s priemerom od 9 do $14 \mathrm{~m} .{ }^{110}$ Ich výskum plánoval zaradit’ do programu ústavu na rok 1941. ${ }^{111}$ O d’alších troch zoskupeniach mohýl na hrebeňoch vrchov Stavenec a Krivarské pri Giraltovciach informoval V. Budaváryho učitel’ K. Sereday. Prvú skupinu tvorilo šest' mohýl, v d’alších dvoch bolo objavených po sedem mohýl. Sám V. Budaváry zistil existenciu d’alších mohýl aj v Šapinci a Štefurove (okr. Svidník) (Budinský-Krička 1967, 289). ${ }^{112}$ Vyše týždňový výskum mohýl VII a VIII v Kožanoch bol definitívne ukončený 10. decembra. ${ }^{113}$

Zvyšok decembra strávil V. Budaváry v ústave v Turčianskom Sv. Martine. Pravdepodobne ešte spracovával výsledky svojho výskumu v Kožanoch, ktorý sa skončil len pred pár dňami. ${ }^{114}$ Neustála pracovná vyt'aženost' riaditel’a ústavu ako i dochádzanie medzi Bratislavou a Turčianskym Sv. Martinom kvôli výučbe počas akademického roka neumožňovala samotnému V. Budavárymu naplno zabezpečovat’ riadny chod ním vedenej inštitúcie. Pomocnú ruku mu však ochotne poskytoval personál Slovenského národného múzea. Ol’ga Kováčiková prepisovala na stroji úradné

107 Archív SAV, f. AÚ SAV - Vedecká činnost', zn. B V, inv. č. 200, č. j. 336/1940, škat. č. 21.

108 Archív SAV, f. AÚ SAV - Vedecká činnost', zn. B V, inv. č. 200, č. j. 312/1940, škat. č. 21.

109 Archív SAV, f. AÚ SAV - Vedecká činnost', zn. B V, inv. č. 200, č. j. 359/1940, škat. č. 21.

110 V liste Ministerstvu školstva a národnej osvety sú uvedené štyri mohyly (prvá mohyla s priemerom 14 m a výškou 180 cm, druhá mohyla s priemerom $12 \mathrm{~m}$ a výškou $150 \mathrm{~cm}$, tretia mohyla s priemerom $9 \mathrm{~m}$ a výškou $100 \mathrm{~cm}$ a štvrtá mohyla s priemerom $13 \mathrm{~m}$ a výškou $150 \mathrm{~cm}$ ). V štúdii z roku 1967 však V. Budinský-Krička uvádza len 2 z nich (Budinský-Krička 1945-46, 289).

Archív SAV, f. AÚ SAV - Vedecká činnost', zn. B V, inv. č. 200, č. j. 358/1940, škat. č. 21.

111 Svedčí o tom list adresovaný Notárskemu úradu v Okruhlom, v ktorom V. Budaváry zist’oval vlastníkov parciel, na ktorých sa mohyly nachádzali. Výskum týchto mohýl sa však nikdy neuskutočnil.

Archív SAV, f. AÚ SAV - Vedecká činnost', zn. B V, inv. č. 200, č. j. 399/1940, škat. č. 21.

112 Na mohyly na pomedzí katastrov Šapinca a Štefurova upozornil V. Budaváryho Juraj Ivanka (Budinský-Krička 1945-46, 266).

113 Archív SAV, f. AÚ SAV - Vedecká činnost', zn. B V, inv. č. 200, č. j. 359/1940, škat. č. 21.

114 10. decembra 1940. 
koncepty, Ján Feja expedoval a donášal poštu, Peter Mendel pomáhal pri konzervovaní, rekonštruovaní a fotografovaní nálezov, Anna Juríková sa starala o úradnú miestnost’ ústavu a Ján Buocik bol nápomocný pri balení a vybal’ovaní nálezov a pri iných technických činnostiach. Pre všetkých preto V. Budaváry žiadal MŠANO o udelenie mimoriadnej odmeny 100 Ks. ${ }^{115}$ Ministerstvo napokon jeho žiadosti vyhovelo. ${ }^{116}$

Tesne pred koncom roka prišla do ústavu pozoruhodná zásielka od Stavebnej správy v Kapušanoch (okr. Prešov). V. Budaváry už túto lokalitu dobre poznal - navštívil ju 6. novembra 1939, kedy tu boli rozrušené viaceré hroby, ktoré obsahovali okrem l’udských kostí aj keramiku, zlomok skleneného pohára a doštičku z kosteného hrebeňa (Budinský-Krička 1957, 356). Aj teraz preto mohol očakávat', že zásielka bude obsahovat' pomerne atraktívne nálezy. Napokon obsahovala jednu hlinenú „amforku“, l'udské kosti a dva sprievodné negatívy. ${ }^{117}$ Keramická nádoba ako i l’udské kosti boli naozaj objavené v hroboch porušených počas stavby železničnej trate medzi Prešovom a Strážskym. Stavebná správa, tušiac, že ide o archeologické pamiatky, ich poslala Štátnemu archeologickému ústavu. Riaditel’ ústavu zaradil hroby na základe keramiky do „staršieho obdobia rímskych provincii““ a prisúdil ich sarmatským Jazygom. ${ }^{118}$ Dôležitost’ tohto nálezu bola o to väčšia, že podobné hroby zo Slovenska dovtedy neboli známe. V. Budaváry v dôsledku toho upozornil stavebnú správu, že v hroboch sa môžu objavit’ aj vzácnejšie artefakty mince, bronzové, železné či sklenené predmety. Zároveň dodal, že v prípade nálezu d’alších hrobov „stojí prednosta Štátneho archeologického ústavu (Vám) hned’ k dispozícii“.

\section{Záver}

Rok 1940 mohol V. Budaváry z vedeckého hl'adiska hodnotit' ako vel'mi prínosný. Okrem toho, že sa mu vd’aka oznamovatel’om podarilo získat' pre Slovenské národné múzeum viaceré historicky cenné predmety (spona z Krivoklátu), objavil na východnom Slovensku pre odbornú obec dovtedy neznáme mohylové pohrebiská z konca eneolitu. Počas letných mesiacov sa naplno venoval ich výskumu a počas menších prieskumov po okolí objavil d’alšie skupiny mohylových násypov. Pomerne úspešný rok bol zakončený nálezom hrobu zo staršej doby rímskej z Kapušian. Napriek tomu sa ani pri najväčšej opatrnosti nedá povedat', že by počiatočné problémy, v ktorých sa ústav nachádzal krátko po svojom založení, v roku 1940 pominuli. Z materiálneho hl’adiska musel ústav neustále bojovat's nedostatočným financovaním od štátu. Práve tento problém s vel'kou pravdepodobnost'ou stál za brzdením terénnych aktivít ústavu v celom prvom polroku. Finančné t’ažkosti sa dokonca podpísali na predčasnom prerušení výskumu mohýl v Kožanoch. Neutešenú situáciu sanovali dobrovol'ní prispievatelia, mimoriadne príspevky od ministerstva či dokonca sám V. Budaváry poskytnutím osobnej pôžičky pre ústav. Všetko toto názorne ukazuje, že ústav v druhom roku svojej existencie ešte nebol vyhovujúco finančne (a ani personálne) zabezpečený. Personálne nedostatočne saturovaná inštitúcia si musela vypomáhat' prácou zamestnancov Slovenského národného múzea. Pomocné ruky boli potrebné na mnohých miestach - pri reštaurovaní, konzervovaní, fotografovaní, písaní listov, upratovaní... Ochotným zamestnancom múzea sa riaditel' ústavu nezabudol odvd'ačit' - na konci roka im navrhol udelenie mimoriadnej odmeny. Koncom roka 1940 nič nenasvedčovalo tomu, že by nasledujúci rok mal byt’ iný. Do roku 1941 teda V. Budaváry vstupoval s obavami o d’alšie finančné zabezpečenie ústavu, no pravdepodobne s o nič nezmenšeným elánom aj nad’alej odkrývat' minulost’ Slovenska. Boj o potvrdenie „životaschopnosti“ ústavu teda pokračoval d’alej.

Poznámka: Táto štúdia bola podporená z prostriedkov grantového projektu VEGA č. 1/0100/19.

\footnotetext{
115 Archív SAV, f. AÚ SAV - Spolupráca s inštitúciami, zn. B VII, inv. č. 269, č. j. 374/1940, škat. č. 55.

116 Archív SAV, f. AÚ SAV - Rozpočet a systematizácia, zn. B X, inv. č. 461, č. j. 55/1941, škat. č. 81.

117 V štúdii z roku 1957 V. Budinský-Krička konštatoval, že v roku 1940 bol okrem l’udských kostí a hlinenej nádoby z lokality získaný aj sklenený pohár. V zásielke sa však nenachádzal (Budinský-Krička 1957, 356, obr. 1: 3).

118 Archív SAV, f. AÚ SAV - Spolupráca s inštitúciami, zn. B VII, inv. č. 269, č. j. 394/1940, škat. č. 55.
} 


\section{Bibliografia}

Bátora, J. 2018: Slovensko v staršej dobe bronzovej. Bratislava.

Bialeková, D. 1992a: Diviacka Nová Ves. In: Bialeková, D. a kol. (eds.): Pramene k dejinám osídlenia Slovenska z konca 5. až 13. storočia. II. zväzok. Stredoslovenský kraj. Nitra, 104-105.

Bialeková, D. 1992b: Diviaky nad Nitricou. In: Bialeková, D. a kol. (eds.): Pramene k dejinám osídlenia Slovenska z konca 5. až 13. storočia. II. zväzok. Stredoslovenský kraj. Nitra, 105.

Bialeková, D. 1992c. Diviaky nad Nitricou, čast' Ješkova Ves nad Nitricou. In: Bialeková, D. a kol. (eds.): Pramene k dejinám osídlenia Slovenska z konca 5. až 13. storočia. II. zväzok. Stredoslovenský kraj. Nitra, 106.

Budaváry, V. 1940: Hrob lovca z konca mladšej doby kamennej z Veselého (okr. Piešt’any) v Slovenskom národnom múzeu. Časopis MSS 31, 1940, 79-80.

Budaváry, V. 1942: Výtvarný prejav slovenského praveku. Martin.

Budinský-Krička, V. 1945-46: Zpráva o terénnych výskumoch Štátneho archeologického ústavu v Turč. Sv. Martine, podniknutých v r. 1939-1945. Historica Slovaca III-IV, 260-267.

Budinský-Krička, V. 1957: Hroby z doby rímskej a st’ahovania národov v Kapušanoch (okr. Prešov). Slovenská archeológia 5-2, 356-362.

Budinský-Krička, V. 1962: Príspevok k štúdiu popolnicových polí nad Hornou Nitrou. Študijné zvesti AÚ SAV 9, 123-130.

Budinský-Krička, V. 1965: Gräberfeld der späten Schnurkeramischen Kultur in Veselé. Slovenská archeológia 13-1, 51-106.

Budinský-Krička, V. 1967: Východoslovenské mohyly. Slovenská archeológia 15-2, 1967, 277-388.

Budinský-Krička, V. 1993: Moja účast' na archeologickom výskume na Slovensku a v Čechách v rokoch 1929-1989. Študijné zvesti AÚ SAV 29, 281-333.

Cernušková, M. 2018: Krivoklát. Bílé Biele Karpaty. Časopis moravsko-slovenského pomezí 2, 24.

Dvorák, P. 2004: Stopy dávnej minulosti 1. Slovensko v praveku. Budmerice.

Filip, J. 1948: Pravěké Československo. Úvod do studia dějin pravěku. Praha.

Furmánek, V. 1986: Kyjatice - eponymní lokalita archeologické kultury. Slovenská archeológia 34-2, 319-330.

Furmánek, V. - Veliačik, L. 1980: Doba bronzová. Slovenská archeológia 28-1, 159-179.

Furmánek, V. - Veliačik, L. - Vladár, J. 1991: Slovensko v dobe bronzovej. Bratislava.

Horñák, M. 2016: Sídliskové stratégie l’udu lužickej kultúry na strednom Považí (Appendix). In: Benediková, L. Katkinová, J. - Budinský-Krička, V. (eds.): Ilava, poloha Porubská dolina. Pohrebisko lužickej kultúry na strednom Považí. Nitra, 454-506. 
Hruboň, A. 2010: 5. pol’ná rota Hlinkovej gardy. Ružomberok.

Hrubý, T. 2014: Zaniknuté stredoveké osady na hornom Ponitrí. In: Tokárová, Z. - Pekár, M. (eds.): Človek, spoločnost', doba. Stretnutie mladých historikov III. Košice, 39-48.

Kudláček, J. 1953: Praveké nálezy z Andača. Slovenská archeológia 1, 199-210.

Marek, M. 2010: Fontes rerum Slovacarum II. Archivum Familiae Motešický. Stredoveké listiny z archívu rodiny Motešický. Trnava.

Neumann, M. 2019: Rok 1939 v slovenskej archeológii. Musaica archaeologica 4-2, 7-26.

Neumann, M. 2020: Vojtech Budinský-Krička a činnost’ Štátneho archeologického ústavu v rokoch 1939-1948. In: Neumann, M. - Mellnerová Šuteková, J. (eds.): Dejiny archeológie. Archeológia v Československu v rokoch 1918-1948. Bratislava, v tlači.

Pivovarová, Z. 1959: Žiarové pohrebisko v Diviakoch. Slovenská archeológia 7-2, 317-327.

Pivovarová, Z. 1965a: K problematike mohýl v lužickej kultúre na Slovensku. Slovenská archeológia 13-1, 107-162.

Pivovarová, Z. 1965b: Výskum v Mikušovciach v rokoch 1961-1963. Archeologické rozhledy 17, $482-487$.

Prehl’ad prác 1941: Prehl’ad prác v Slovenskom národnom múzeu (1940). Časopis MSS 32, 50-58.

Ruttkay, A. 1965: Nové nálezy z horného Ponitria. Študijné zvesti AÚ SAV 15, 189-214.

Ruttkay, M. 2007: Záchranný archeologický výskum v Nitre na Svätoplukovom námestí. In: Březinová, G. Samuel, M. a kol. (eds.): „Tak čo, našli ste niečo?“ Svedectvo archeológie o minulosti Mostnej ulice v Nitre. Nitra, 131-144.

Ruttkay, M. 2018: Hrobové nálezy z Nitry - Svätoplukovho námestia. In: Bátora, J. - Kujovský, R. - Ruttkay, M. Vladár, J. (eds.): Anton Točík. Legenda slovenskej archeológie. Nitra, 145-160.

Sklenár, K. 2005: Biografický slovník českých, moravských a slezských archeologů. Praha.

Šubajikková-Pivovarová, Z. 1961: Ďalšie nálezy z lužického pohrebiska v Diviakoch nad Nitricou. Študijné zvesti AÚ SAV 6, 1961, 237-240.

Veliačik, L. 1975: Pohrebisko lužickej kultúry v Diviakoch nad Nitricou. Archeologické výskumy a nálezy na Slovensku v roku 1974, 110-112.

Veliačik, L. 1976: Výskum pohrebiska lužickej kultúry v Diviakoch nad Nitricou. Archeologické výskumy a nálezy na Slovensku v roku 1975, 1976, 210-213.

Veliačik, L. 1991: Beitrag des Gräberfeldes in Diviaky nad Nitricou zur Chronologie der Denkmäler Lausitzer Kultur in der Slowakei. Slovenská archeológia 39, 143-214.

Vojáček, L. - Kolárik, J. - Gábriš, T. 2011: Československé právne dejiny (1918-1992). Text a pramene. Bratislava. 


\section{Periodická tlač}

Cenné archeologické vykopávky na východnom Slovensku. Slovák, 27. júl 1940, roč. 22, č. 176, 3.

Lanská práca Slovenského národného múzea (Z činnosti jednotlivých odborov). Slovák, 8. máj 1940, roč. 22, č. 107 , 7.

Nález vzácnej bronzovej spony v Krivokláte pri Púchove. Slovák, 21. august 1940, roč. 22, č. 198, 8.

Našli hrob básnika Janka Krála. Slovák, 16. október 1940, roč. 22, č. $246,7$.

Objavili pät' tisíc rokov staré pohrebište. Slovák, 12. júl 1940, roč. 22, č. 162, 7.

Objav popolnicového pol’a v Diviakoch nad Nitricou. Gardista, 28. november 1940, roč. 2, č. 66, 5.

Prevezenie pozostatkov Janka Krála. Slovák, 3. november 1940, roč. 22, č. 261, 10.

Prevezenie pozostatkov Janka Krála zo Zlatých Moraviec do martinského národného cintorína. Slovák, 5. november 1940, roč. 22, č. 262, 2.

Pri Andači našli starobylé pohrebište. Slovák, 23. október 1940, roč. 22, č. 252, 4.

Pri Piešt’anoch objavili rozsiahle pohrebište z doby bronzovej. Slovák, 21. september 1940, roč. 22, č. 225, 2.

Rekonštrukčné práce na železničnej trati Zbehy-Leopoldov. Slovák, 12. september 1940, roč. 22, č. 217, 5.

Staroslovenské pohrebište pri Nitre. Slovák, 26. október 1940, roč. 22, č. 255, 4.

Stručný prierez históriou obce. Diviacke noviny, júl 2010, č. 2, 4.

Telesné pozostatky Janka Král’a prevezú do Turčianskeho Sv. Martina. Slovák, 30. október 1940, roč. 22, č. 258, 2.

Telesné pozostatky Janka Krála prevezú na cintorín do Turčianskeho Sv. Martina. Slovák, 22. október 1940, roč. 22, č. 251,3 .

V Nitre našli vel'ké pohrebište. Slovák, 9. október 1940, roč. 22, č. 240, 4.

V Nitre upravujú Tisovo námestie. Slovák, 29. máj 1940, roč. 22, č. 124, 6.

Vyše 6000 robotníkov na stavbe novej železnice Strážske - Vranov - Prešov. Slovák, 26. jún 1940, roč. 22, č. 149, 4.

Zaujímavé nálezy v Nitre. Slovák, 5. jún 1940, roč. 22, č. 130, 6.

Z minulých dní. Nový svet, 9. november 1940, roč. 15, č. 45, 2.

\section{Archívne pramene}

Archív SAV, f. AÚ SAV - Rozpočet a systematizácia, zn. B X, inv. č. 460, č. j. 152/1940, škat. č. 81. Archív SAV, f. AÚ SAV - Rozpočet a systematizácia, zn. B X, inv. č. 460, č. j. 175/1940, škat. č. 81. Archív SAV, f. AÚ SAV - Rozpočet a systematizácia, zn. B X, inv. č. 460, č. j. 225/1940, škat. č. 81. Archív SAV, f. AÚ SAV - Rozpočet a systematizácia, zn. B X, inv. č. 460, č. j. 302/1940, škat. č. 81. Archív SAV, f. AÚ SAV - Rozpočet a systematizácia, zn. B X, inv. č. 460, č. j. 334/1940, škat. č. 81. Archív SAV, f. AÚ SAV - Rozpočet a systematizácia, zn. B X, inv. č. 461, č. j. 55/1941, škat. č. 81. Archív SAV, f. AÚ SAV - Spolupráca s inštitúciami, zn. B VII, inv. č. 269, č. j. 6/1940, škat. č. 55. Archív SAV, f. AÚ SAV - Spolupráca s inštitúciami, zn. B VII, inv. č. 269, č. j. 7/1940, škat. č. 55. Archív SAV, f. AÚ SAV - Spolupráca s inštitúciami, zn. B VII, inv. č. 269, č. j. 8/1940, škat. č. 55. Archív SAV, f. AÚ SAV - Spolupráca s inštitúciami, zn. B VII, inv. č. 269, č. j. 9/1940, škat. č. 55. Archív SAV, f. AÚ SAV - Spolupráca s inštitúciami, zn. B VII, inv. č. 269, č. j. 46/1940, škat. č. 55. Archív SAV, f. AÚ SAV - Spolupráca s inštitúciami, zn. B VII, inv. č. 269, č. j. 54/1940, škat. č. 55. Archív SAV, f. AÚ SAV - Spolupráca s inštitúciami, zn. B VII, inv. č. 269, č. j. 91/1940, škat. č. 55. Archív SAV, f. AÚ SAV - Spolupráca s inštitúciami, zn. B VII, inv. č. 269, č. j. 156/1940, škat. č. 55. Archív SAV, f. AÚ SAV - Spolupráca s inštitúciami, zn. B VII, inv. č. 269, č. j. 374/1940, škat. č. 55. Archív SAV, f. AÚ SAV - Spolupráca s inštitúciami, zn. B VII, inv. č. 269, č. j. 394/1940, škat. č. 55. Archív SAV, f. AÚ SAV - Vedecká činnost', zn. B V, inv. č. 200, č. j. 66/1940, škat. č. 21. Archív SAV, f. AÚ SAV - Vedecká činnost', zn. B V, inv. č. 200, č. j. 95/1940, škat. č. 21. Archív SAV, f. AÚ SAV - Vedecká činnost', zn. B V, inv. č. 200, č. j. 110/1940, škat. č. 21. Archív SAV, f. AÚ SAV - Vedecká činnost', zn. B V, inv. č. 200, č. j. 124/1940, škat. č. 21. Archív SAV, f. AÚ SAV - Vedecká činnost', zn. B V, inv. č. 200, č. j. 126/1940, škat. č. 21. Archív SAV, f. AÚ SAV - Vedecká činnost', zn. B V, inv. č. 200, č. j. 155/1940, škat. č. 21. Archív SAV, f. AÚ SAV - Vedecká činnost', zn. B V, inv. č. 200, č. j. 166/1940, škat. č. 21. 
Archív SAV, f. AÚ SAV - Vedecká činnost', zn. B V, inv. č. 200, č. j. 156/1940, škat. č. 21. Archív SAV, f. AÚ SAV - Vedecká činnost', zn. B V, inv. č. 200, č. j. 171/1940, škat. č. 21. Archív SAV, f. AÚ SAV - Vedecká činnost', zn. B V, inv. č. 200, č. j. 173/1940, škat. č. 21. Archív SAV, f. AÚ SAV - Vedecká činnost', zn. B V, inv. č. 200, č. j. 242/1940, škat. č. 21. Archív SAV, f. AÚ SAV - Vedecká činnost', zn. B V, inv. č. 200, č. j. 249/1940, škat. č. 21. Archív SAV, f. AÚ SAV - Vedecká činnost', zn. B V, inv. č. 200, č. j. 265/1940, škat. č. 21. Archív SAV, f. AÚ SAV - Vedecká činnost', zn. B V, inv. č. 200, č. j. 282/1940, škat. č. 21. Archív SAV, f. AÚ SAV - Vedecká činnost', zn. B V, inv. č. 200, č. j. 312/1940, škat. č. 21. Archív SAV, f. AÚ SAV - Vedecká činnost', zn. B V, inv. č. 200, č. j. 313/1940, škat. č. 21. Archív SAV, f. AÚ SAV - Vedecká činnost', zn. B V, inv. č. 200, č. j. 327/1940, škat. č. 21. Archív SAV, f. AÚ SAV - Vedecká činnost', zn. B V, inv. č. 200, č. j. 336/1940, škat. č. 21. Archív SAV, f. AÚ SAV - Vedecká činnost', zn. B V, inv. č. 200, č. j. 358/1940, škat. č. 21. Archív SAV, f. AÚ SAV - Vedecká činnost', zn. B V, inv. č. 200, č. j. 359/1940, škat. č. 21. Archív SAV, f. AÚ SAV - Vedecká činnost', zn. B V, inv. č. 200, č. j. 359/1940, škat. č. 21. Archív SAV, f. AÚ SAV - Vedecká činnost', zn. B V, inv. č. 200, č. j. 399/1940, škat. č. 21.

\section{Internetové zdroje}

https://absolventi.uniba.sk/index.do (citované dňa 21. apríla 2020)

\section{Použité skratky}

AÚ SAV - Archeologický ústav Slovenskej akadémie vied

č. - číslo

č. j. - číslo jednotky

f. - fond

inv. - inventárny

Ks - koruna slovenská

MSS - Muzeálna slovenská spoločnost'

MŠANO - Ministerstvo školstva a národnej osvety

okr. - okres

roč. - ročník

SAV - Slovenská akadémia vied

sv. - svätý

škat. - škatula

Turč. - Turčiansky

zn. - značka

\section{Summary}

From the scientific point of view, year 1940 was for V. Budaváry as the head of State Archaeological Institute very fruitful. Beside the fact that he acquired few priceless finds for the collections of Slovak National Museum (e.g. brooch from Krivoklát), he discovered till then unknown late Neolithic burial mounds in the eastern Slovakia. During the summer he spent couple of weeks excavating these mounds (cadasters of Kožany and Kurima) and prospecting their wide neighbourhood (with great success - he found groups of mounds aligned on the ridges). Next months brought various small rescue excavations (Veselé, Nitra, Andač) which were ended by the find of the early Roman period grave in Kapušany. Nevertheless, initial problems of newly established institute were not gone. V. Budaváry had to struggle against insufficient state funding. This ongoing problem substantially hampered institute's activities in the first half year. These difficulties led to the abrupt interruption of excavation in Kožany. Sit- 
uation was partially saved by voluntary contributors, extraordinary donation or even by the loan from V. Budaváry. All this clearly illustrates that after 1 year of existence the life of the Institute was no bed of roses. Personally unsaturated institution was forced to seek for help elsewhere. Great assistance provided especially employees of Slovak National Museum. V. Budaváry did not forget to repay for their help - he proposed for them special bounty which was approved without any reservations by the Ministry of Education. The end of year was not indicative of any changes in the future one. Thus the beginning of the next year was accompanied by concerns for provision of the Institute. Nevertheless, it did not diminish V. Budaváry's resolution to uncover Slovak prehistory. 